\title{
Modeling dissolved oxygen dynamics and hypoxia
}

\author{
M. A. Peña ${ }^{1}$, S. Katsev ${ }^{2}$, T. Oguz ${ }^{3}$, and D. Gilbert ${ }^{4}$ \\ ${ }^{1}$ Fisheries \& Oceans Canada, Institute of Ocean Sciences, P.O. Box 6000, Sidney, B.C. V8L 4B2, Canada \\ ${ }^{2}$ Large Lakes Observatory and Department of Physics, University of Minnesota Duluth, 2205 E. 5th Street, Duluth, \\ Minnesota 55812, USA \\ ${ }^{3}$ Institute of Marine Sciences, Middle East Technical University, Erdemli, Turkey \\ ${ }^{4}$ Fisheries \& Oceans Canada, Institut Maurice-Lamontagne, 850 route de la Mer, Mont-Joli, Québec G5H 3Z4, Canada
}

Received: 31 August 2009 - Published in Biogeosciences Discuss.: 24 September 2009

Revised: 1 March 2010 - Accepted: 3 March 2010 - Published: 9 March 2010

\begin{abstract}
Hypoxia conditions are increasing throughout the world, influencing biogeochemical cycles of elements and marine life. Hypoxia results from complex interactions between physical and biogeochemical processes, which can not be understood by observations alone. Models are invaluable tools at studying system dynamics, generalizing discrete observations and predicting future states. They are also useful as management tools for evaluating site-specific responses to management scenarios. Here we review oxygen dynamics models that have significantly contributed to a better understanding of the effects of natural processes and human perturbations on the development of hypoxia, factors controlling the extent and temporal variability of coastal hypoxia, and the effects of oxygen depletion on biogeochemical cycles. Because hypoxia occurs in a variety of environments and can be persistent, periodic or episodic, models differ significantly in their complexity and temporal and spatial resolution. We discuss the progress in developing hypoxia models for benthic and pelagic systems that range from simple box models to three dimensional circulation models. Applications of these models in five major hypoxia regions are presented. In the last decades, substantial progress has been made towards the parameterization of biogeochemical processes in both hypoxic water columns and sediments. In coastal regions, semiempirical models have been used more frequently than mechanistic models to study nutrient enrichment and hypoxia relationships. Recent advances in three-dimensional coupled physical-ecological-biogeochemical models have allowed a better representation of physical-biological interactions in these systems. We discuss the remaining gaps in process de-
\end{abstract}

\section{Correspondence to: M. A. Peña} (angelica.pena@dfo-mpo.gc.ca) scriptions and suggest directions for improvement. Better process representations in models will help us answer several important questions, such as those about the causes of the observed worldwide increase in hypoxic conditions, and future changes in the intensity and spread of coastal hypoxia. At the same time, quantitative model intercomparison studies suggest that the predictive ability of our models may be adversely affected by their increasing complexity, unless the models are properly constrained by observations.

\section{Introduction}

Hypoxia $\left(\mathrm{O}_{2}\right.$ concentrations of $\left.<63 \mu \mathrm{M}\right)$ in the ocean influence biogeochemical cycles of elements and may have severe negative impacts on marine ecosystems, such as mortality of benthic fauna, fish kills, habitat loss, and physiological stress (Levin et al., 2009; Ekau et al., 2009). Hypoxia occurs in a variety of coastal environments including fjords, eastern boundary upwelling regions, semi-enclosed seas and large estuaries. It can occur naturally in bottom waters of silled basins and fjords with restricted circulation (e.g. the Black Sea) and in coastal upwelling regions where oxygen-poor and nutrient-rich deep waters are transported onto continental shelves (e.g. eastern Pacific Ocean). It also results from anthropogenic fertilization of coastal waters by riverine nutrient supply, which is in part responsible for the exponential increase in the number of hypoxic "dead zones" in the coastal oceans since the 1960s (Diaz and Rosenberg, 2008). By enhancing primary production, nutrient loading leads to higher sedimentation fluxes of organic matter and increased microbial consumption of oxygen below the pycnocline. At the same time, riverine inputs of fresh water increase the vertical

Published by Copernicus Publications on behalf of the European Geosciences Union. 
density gradient, which reduces the transfer of oxygen from the surface to deep water. Internal feedback mechanisms such as legacy storage of organic carbon in the sediments (Turner et al., 2008) also influence oxygen consumption. Global warming may exacerbate hypoxia conditions through reduced oxygen solubility, enhanced stratification and reduced winter ventilation of the water column. Given the significance and the recent increase in frequency of coastal hypoxic events, it is important to improve our understanding of the natural and anthropogenic drivers of hypoxia and the internal feedback mechanisms.

Hypoxia results from an imbalance between biological production and consumption of oxygen, air-sea fluxes, and its transport by physical processes. Oxygen depletion can be persistent, periodic or episodic. Persistent hypoxic conditions are observed in numerous fjords and semi-enclosed seas with year-round density stratification and low flushing rates (e.g. Baltic Sea), over deep trenches (e.g. Cariaco Basin), and in oxygen minimum zones (OMZ) where weak ocean ventilation in association with biogeochemical transformations maintains low oxygen levels (e.g. eastern tropical Pacific Ocean). The strong vertical oxygen gradients in these regions exert a considerable influence on the biogeochemical properties and organism distributions. Permanent hypoxic regions play important roles in the global nitrogen cycle, being the main areas of nitrogen loss (as $\mathrm{N}_{2}$ and $\mathrm{N}_{2} \mathrm{O}$ ) to the atmosphere through denitrification and anammox processes (e.g. Codispoti et al., 2001; Kuypers et al., 2003). These regions are also involved in the production of important greenhouse gases such as $\mathrm{N}_{2} \mathrm{O}$ (e.g. Bange et al., 1996; Naqvi et al., 2000) and $\mathrm{CH}_{4}$ (e.g. Cicerone and Oremland, 1988). Significant progress has been made to incorporate these complex biogeochemical cycles in models of low-oxygen environments in semi-enclosed seas such as the Black Sea (Oguz et al., 2000; Konovalov et al., 2006; Yakushev et al., 2007; Grégoire et al., 2008), but not in other regions (e.g. OMZ). A time-series analysis of $\mathrm{O}_{2}$ concentrations in the tropical ocean revealed vertical expansion of the OMZ in the eastern tropical Atlantic and the equatorial Pacific over the past 50 years (Stramma et al., 2008). This finding supports climate model predictions of dissolved oxygen declines and expansion of the OMZ under global warming conditions (Matear and Hirst, 2003). Expansion of the OMZ could have significant environmental and ecological impacts and will inevitably alter the closely linked global nitrogen and carbon cycles.

Periodic oxygen depletion has been observed in many systems and may occur more often than seasonally, lasting from hours to weeks. Seasonal fluctuations in oxygen resulting in hypoxia are usually driven by summer stratification of the water column coupled with increased production of organic matter. The settling and subsequent decomposition of this organic matter promotes oxygen depletion in bottom waters as indicated by models of, for example, the inner continental shelf of the northern Gulf of Mexico (Hetland and DiMarco,
2008) and Chesapeake Bay (Xu and Hood, 2006). Large diurnal fluctuations of oxygen between nighttime hypoxia and daytime supersaturation have been observed in shallow tidal creeks, lagoons, and estuaries, (e.g. D'Avanzo and Kremer, 1994). In a coastal embayment of the Chesapeake Bay, model simulations indicate that high primary production during daytime results in supersaturated $\mathrm{O}_{2}$ levels, while at night respiration overwhelms the $\mathrm{O}_{2}$ supply, often leading to hypoxia (Shen et al., 2008). Infrequent episodic oxygen depletion with less than one event per year seems to be the first indication that a system has reached a critical point of eutrophication, which, in combination with physical processes that restrict water exchange, can tip the system into hypoxia (Diaz and Rosenberg, 2008). Fluctuations in the extent and duration of low oxygen events can lead to significant ecological and economic impacts.

In coastal regions, hypoxia results from complex interactions between climate, weather, basin morphology, circulation patterns, water retention times, freshwater inflows, stratification, mixing and nutrient loadings (Druon et al., 2004; Gilbert et al., 2005). Because of the numerous physical and biogeochemical processes involved, the development of numerical models that enable $\mathrm{O}_{2}$ responses to the external/internal environment to be estimated is essential for understanding the dynamics of hypoxia. Several model studies using empirical or mechanistic type models have been carried out in coastal hypoxic regions with different physical settings and biogeochemistry (Fig. 1). Models are useful tools in scientific research of hypoxa condition and for planning and forecasting site-specific responses to different management scenarios; they are needed to provide advice to policy makers about the probable effectiveness of various remedial actions at affordable costs.

Biogeochemical models that include the oxygen cycle have contributed to improved understanding of diverse aspects of hypoxia, such as processes responsible for its development (Druon et al., 2004), controls on its extent and temporal variability (Sohma et al., 2008), its impact on biogeochemical cycles (Oguz et al., 2000), issues related to eutrophication (Grégoire et al., 2008), and effects of climate change on $\mathrm{O}_{2}$ concentrations (Matear and Hirst, 2003). They also have been useful in providing guidelines for setting goals of nutrient reductions (e.g. Cerco and Cole, 1993, Scavia and Donnelly, 2007). Because hypoxia occurs in regions with different physical setting and biogeochemistry, models differ significantly in their temporal and spatial resolution. Estuarine and coastal regions pose a further challenge to modellers. Substantial river discharges and relatively shallow waters often result in large fluctuations and strong spatial gradients in physical and biogeochemical variables that have proven difficult to replicate in models. How important it is for models to capture this variability when assessing the potential impacts of local management strategies or predicting impacts of future conditions on hypoxia remains unclear. 


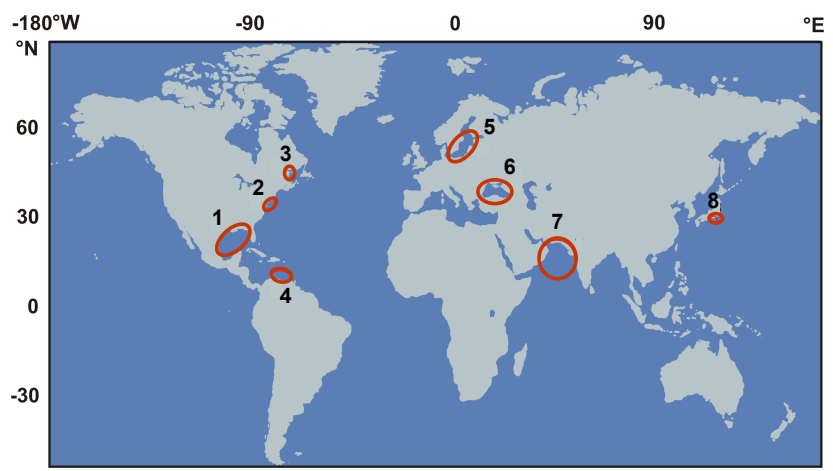

Fig. 1. Map of hypoxic sites where modeling studies have been carried out. 1, Gulf of Mexico; 2, Chesapeake Bay; 3, Gulf of St. Lawrence; 4, Cariaco Basin; 5, Baltic Sea; 6, Black Sea; 7, Arabian Sea; 8, Tokyo Bay.

This review is a contribution to SCOR Working Group 128 , which aims to synthesize the state of the science for several aspects of coastal hypoxia (Zhang et al., 2009). Here, we provide an overview of the state of the art and major findings from recent efforts to model hypoxia, focusing primarily on mechanistic models. We start with a brief description of major physical and biogeochemical processes determining oxygen dynamics and their representation in models (Sect. 2), followed by an overview of studies dealing with modeling the effect of hypoxia on biogeochemical cycles and ecosystems (Sect. 3). Then, in section 4, we present four case studies (Northern Gulf of Mexico, Black Sea, Baltic Sea and OMZ) that illustrate the use of oxygen dynamics models in the study of oxygen deficient environments. Finally, we summarize our main findings, identify model components that require further development, and discuss possible future research directions in modeling hypoxic conditions.

\section{Major physical and biogeochemical processes}

The concentration of oxygen in the ocean is dependent on air-sea fluxes, physical transports, and biogeochemical processes that produce and consume $\mathrm{O}_{2}$ in the water column and in bottom sediments. In mechanistic models, $\mathrm{O}_{2}$ is represented as a state variable and its dynamic is described by partial differential equations that satisfy mass conservation (i.e. the total amount of oxygen from all sources is constant). Most models are developed for a specific region and, depending on the application and available information, differ markedly in the level of complexity and temporal and spatial resolution. For example, models may include only biogeochemical processes in the water column without taking into account sediment processes, and vice-versa. In general, the importance of including benthic processes increases with decreasing water depth because greater proportions of sinking organic matter reach the seafloor in shallow marine systems.
Simple models use empirical or semi-empirical functions to describe oxygen sources and sinks. More complex models (Fig. 2) couple mechanistic physical and biogeochemical processes that simulate in detail benthic-pelagic $\mathrm{O}_{2}$ dynamics. These processes are discussed in more detail below.

\subsection{Air-sea exchange of oxygen}

Oxygen levels in ocean surface water are strongly dependent on air-sea gas exchange where the invasion of $\mathrm{O}_{2}$ can, at times, alleviate hypoxia in coastal oceans and estuaries. Oxygen fluxes across the sea surface, $F_{\mathrm{O}_{2}}\left(\mathrm{~mol} \mathrm{~m}^{-2} \mathrm{~s}^{-1}\right)$, result from the difference in partial pressure of the gas in the ocean surface layer and in the atmosphere and can be described as:

$F_{\mathrm{O}_{2}}=k\left(\mathrm{O}_{2}^{\text {surf }}-\mathrm{O}_{2}^{\text {sat }}\right)$

where $\mathrm{O}_{2}^{\text {sat }}$ is the saturation concentration which depends on sea-surface temperature and salinity (e.g. Garcia and Gordon, 1992), $\mathrm{O}_{2}^{\text {surf }}$ is the oxygen concentration in the surface mixed layer, and $k$ is the gas transport velocity or piston velocity. Various parameterizations of $k$ are in use. The most widely used parameterizations are based on non-linear functions of wind speed, and to a lesser extent, on sea surface temperature and salinity (e.g. Wanninkhof, 1992). However, it is well known that other factors such as bubble entrainment, surfactants films, and surface roughness can also affect the gas transfer processes. More recent parameterizations include gas transfer due to bubbles, friction velocity, sea surface roughness, and significant wave height (e.g. Fangohr and Woolf, 2007; Wanninkhof et al., 2009) but, so far, there is no general agreement about their relative accuracy.

\subsection{Advective-dispersive transport processes}

Doney et al. (2004) showed how critical it is to include realistic physics if one hopes to reproduce the biogeochemistry with any degree of reliability. Oxygen concentrations in the water column are affected by fluxes across the air-sea interface (Eq. 1) and across the sediment-water interface (Eq. 3). Within the water column itself, the oxygen budget can be expressed by the following oxygen balance equation:

$$
\begin{gathered}
\frac{\partial \mathrm{O}_{2}}{\partial t}+u \frac{\partial \mathrm{O}_{2}}{\partial x}+v \frac{\partial \mathrm{O}_{2}}{\partial y}+w \frac{\partial \mathrm{O}_{2}}{\partial z}-K_{z} \frac{\partial^{2} \mathrm{O}_{2}}{\partial z^{2}} \\
-K_{H}\left(\frac{\partial^{2} \mathrm{O}_{2}}{\partial x^{2}}+\frac{\partial^{2} \mathrm{O}_{2}}{\partial y^{2}}\right)+\mathrm{nct}=0
\end{gathered}
$$

in which the first term represents the local rate of change of oxygen concentration with time. The second and third terms represent advection by currents in the east-west and north-south directions respectively. In box models, flow data from field observations or from prognostic three-dimensional models of ocean circulation are required to represent advection by currents at the boundaries (Cerco and Cole, 1993; Bierman et al., 1994). The fourth term represents vertical 


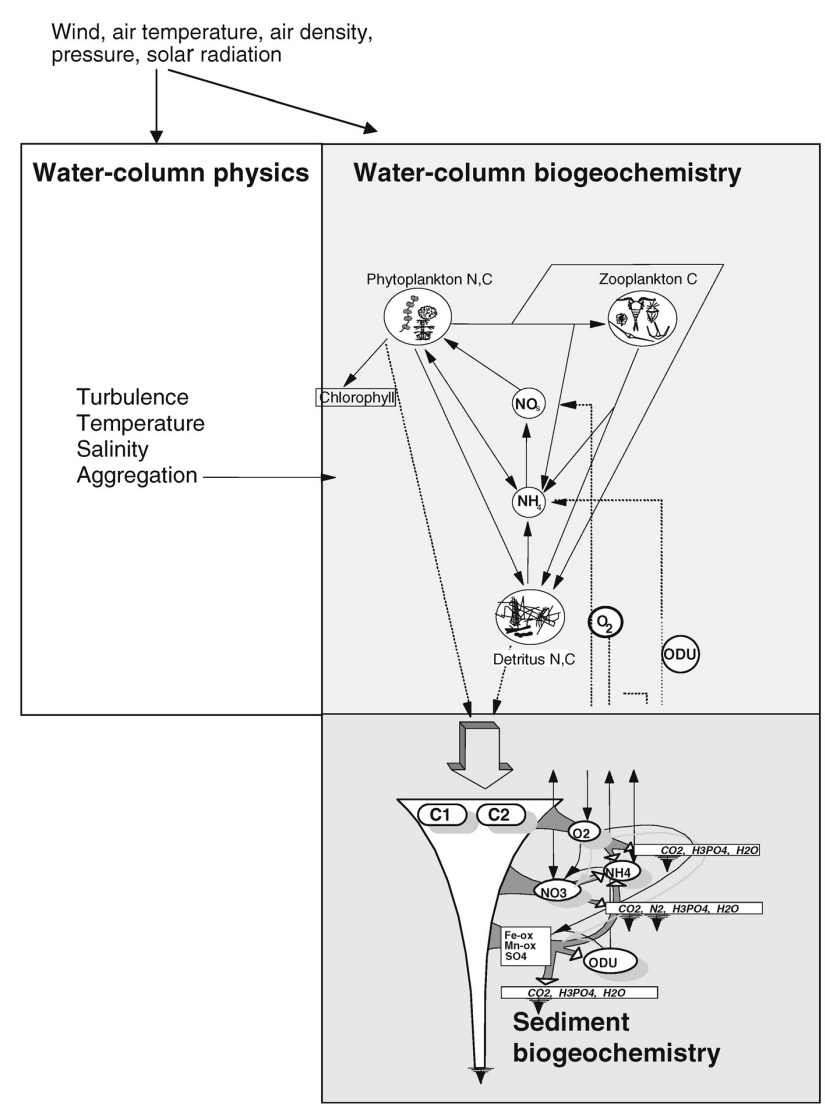

Fig. 2. Schematic representation of a 1-D fully coupled model describing the water-column physics (left), water-column biogeochemistry (top right) and sediment biogeochemistry (bottom right) (after Soetaert and Middelburg, 2009).

transport by upwelling or downwelling. The fifth term represents vertical mixing in which $K_{z}(x, y, z)$ is the vertical eddy diffusivity. The sixth term represents horizontal diffusion where $K_{H}(x, y, z)$ is the horizontal eddy diffusivity. Finally, the non-conservative terms (nct) represent processes such as photosynthesis, respiration and bacterial organic matter remineralization.

In areas of reduced advective transports and horizontal diffusion (e.g. fjords and semi-enclosed seas with shallow sills), waters beneath the pycnocline can only be oxygenated by vertical mixing which is strongly reduced due to the presence of stratification. Thus, such water bodies are often prone to develop hypoxic/anoxic conditions below sill depths (Eilola et al., 2009) due to lack of ventilation. Interannual variability of the intensity of ventilation can be found in connection with variability of the vertical stratification as shown, for example, by Bendtsen et al. (2009) using $k-c$ turbulence closure scheme. Their simulation suggests that less ventilation of bottom water due to greater stratification was responsible for an extreme hypoxic event in the autumn 2002 in the southern Kattegat region.
The vertical mixing term, $K_{z} \partial^{2} \mathrm{O}_{2} / \partial z^{2}$, plays a key role in the local oxygen balance (Eq. 2). Its magnitude depends on the value of vertical eddy diffusivity $K_{z}$, which is highly variable in both space and time as it depends on the gradient Richardson number, $R i$, which expresses the ratio of turbulence suppression by stratification relative to vertical shear production of turbulence. Thus, strong vertical density gradients (stratification) and/or weak current shears can suppress vertical mixing and be favorable to hypoxia. Key physical factors that produce stronger vertical density gradients $(\partial \rho / \partial z)$ include freshwater inputs from rivers or precipitation, and warmer surface temperatures from absorption of solar radiation or sensible heat input. Factors responsible for producing enhanced vertical shear $(\partial V / \partial z)$ and enhanced vertical mixing include tidal and wind-driven currents, inertial waves, internal tides, surface heat losses to the atmosphere, surface waves and Langmuir cells (Kantha and Clayson, 2000). Vertical overturns due to shear instability $(R i<1 / 4)$ generally occur at vertical scales that are smaller than the vertical grid spacing, and so must be parameterized in turbulence closure models (e.g. Mellor and Yamada, 1982).

In a one-dimensional (1-D) model that couples watercolumn physics with pelagic biogeochemistry in a $50 \mathrm{~m}$ water column and with benthic biogeochemistry in a $60 \mathrm{~cm}$ sediment column, Soetaert and Middelburg (2009) show how stratification affects vertical mixing intensity and oxygen concentrations in the water column. Their model parameterized vertical mixing by using the $k-\varepsilon$ turbulence closure scheme of Gaspar et al. (1990). In a study of the water column oxic/anoxic interface in the Black and Baltic Seas, Yakushev et al. (2007) used the General Ocean Turbulence Model (GOTM, Umlauf et al., 2005), a one-dimensional model that offers the user the possibility of using several different statistical turbulence closure schemes.

Such 1-D models are useful for the insight that they can provide about the relative importance of processes that are usually too expensive to include in 2-D or 3-D models in terms of computing time. However, by design, they do not allow us to consider the role of wind-driven coastal upwelling or downwelling which sometimes play an important role in oxygen dynamics. For example, in Long Island Sound, Wilson et al. (2008) argue that changes in wind-driven upwelling are responsible for the continued increases of hypoxic conditions despite major reductions in organic matter load from New York City.

\subsection{Production and consumption of oxygen}

Oxygen and organic matter are produced via photosynthesis and are consumed during respiration and remineralization of organic matter in the water column and sediments. The coupling between oxygen production and consumption may occur on a variety of space and time scales, as the organic matter cycles through the food web, and diffuses, advects, or 
settles out of the area in which it was originally produced. Thus, the balance between oxygen production and consumption will shift with time, with short or extended periods of positive or negative imbalance. Biogeochemical processes consuming oxygen in the water column differ from those in coastal sediments due to differences in transport processes (eddy diffusion versus molecular and particle settling versus bioturbational mixing), relevant time scales and availability of particulate and dissolved substances.

\subsubsection{Water column}

Oxygen production by phytoplankton is usually modeled as non-linear function of light and nutrient (e.g. Los et al., 2008). In most biogeochemical models, $\mathrm{O}_{2}$ is not represented in the modeled biological processes directly but is coupled to the food web production and consumption of organic matter through the use of stoichiometric ratios (e.g. Xu and Hood, 2006; Gregoire et al., 2008). These models range in complexity from relatively simple (if any) model formulations for food web interactions and organisms other than phytoplankton (e.g. Park et al., 1996) to complex ecosystem models with several functional compartments (e.g. Los et al., 2008). Alternatively, empirical or semi-empirical formulations might be used to compute primary productivity, net productivity (photosynthesis minus community respiration) and remineralization rates (e.g. Justić et al., 1996; Borsuk et al., 2001; Scavia et al., 2006).

Because nitrogen is usually the main nutrient limiting phytoplankton production in the ocean, most biogeochemical models are expressed in nitrogen units (e.g. Peña, 2003). Thus, the rates of biological production and consumption of oxygen are calculated from the magnitude of the associated nitrogen flux assuming constant stoichiometric (Redfieldlike) ratios (Table 1). However, the assumption of fixed ratios is flawed and can lead to significant errors in model output. For example, Paulmier et al. (2009) compared the stoichiometries of organic matter and of its remineralization (aerobic and anaerobic) used in common biogeochemical ocean models. They found that the elemental composition of the organic matter simulated in biogeochemical models have consequences for the simulated fluxes of oxygen. Assuming organic matter rich in hydrogen, such as lipids or protein, implies more consumption of $\mathrm{O}_{2}$ during aerobic remineralization, and also more consumption of $\mathrm{HNO}_{3}$ and more loss of fixed nitrogen as $\mathrm{N}_{2}$ by denitrification, but less production of $\mathrm{N}_{2}$ per $\mathrm{HNO}_{3}$ consumption.

Oxygen is consumed during respiration and remineralization of organic matter, nitrification, and redox reactions (Fig. 3). Respiratory activity can be divided between basal (resting) respiration, that associated with biosynthesis of biomass and that which supports behavior (Flynn, 2005). In most models, respiration is simply parameterized as a loss term which is either a fraction of the growth rate (e.g. Sohma et al., 2008) or a fraction of the biomass (e.g. Neu-

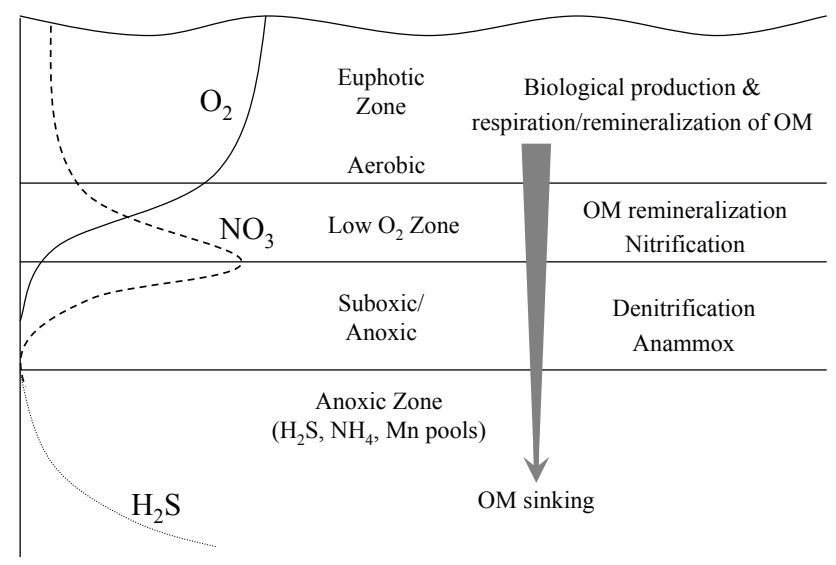

Fig. 3. Schematic vertical profile of water column processes showing the well oxygenated euphotic zone, oxycline/upper nitricline region, suboxic zone and anoxic layer. $\mathrm{OM}=$ organic matter.

mann, 2000). In nitrogen based models, the respiration loss term is represented by the excretion of ammonia. Mortality and food egestion produce dissolved and particulate organic matter (detritus) which can be further divided according to its remineralization rate into fast-labile, slow-labile and refractory parts. Detritus can also be divided according to its sinking rate into suspended, slow and fast sinking detritus. Choosing a value for the sinking rate parameter clearly poses a problem for modelers. In reality, particulate organic matter in marine systems comprises a spectrum of sizes, with an associated range in particle sinking velocities. To make matters even more complicated, particle size distributions can vary due to processes such as aggregation and disagregation.

The remineralization of organic matter consumes oxygen both directly through oxic respiration and indirectly through oxidation of a variety of metabolites (e.g. Mn(II), Fe(II), $\mathrm{S}(-\mathrm{II})$ ). Several models indicate that detritus remineralization is the main consumer of oxygen in sub-surface waters (Oguz et al., 2000; Grégoire and Lacroix, 2001; Xu and Hood, 2006). Water column anoxic conditions arise from an imbalance in the transport rates of organic matter and oxygen into deeper layers, such that oxygen is depleted and an excess of organic material is left to be remineralized, predominantly by chemolitotrophic bacteria. The particulate organic matter not remineralized in the water column is deposited to the sediments.

In oxygenated waters, detritus is remineralized at the expense of oxygen (Table 1, Eq. 3) and can be parameterized as a first order decay relation of detritus available for decomposition (Justić et al., 2002) or be determined from empirical formulations such as the exponential decrease in sinking flux of organic carbon with water depth (Buesseler et al., 2007). In addition, remineralization can be modeled as a function of temperature and $\mathrm{O}_{2}$ (e.g. Shen et al., 2008). The oxygen dependence can be modeled as a linear function (e.g. Yakushev and Neretin, 1997) or as a non-linear function, 
Table 1. Idealized biogeochemical processes/reactions.

\begin{tabular}{llr}
\hline No. & Biogeochemical processes/reactions & $\mathrm{O}_{2}: \mathrm{N}$ ratios \\
\hline & Production using $\mathrm{NO}_{3}-\mathrm{N}:$ & \\
1 & $106 \mathrm{CO}_{2}+16 \mathrm{NO}_{3}^{-}+\mathrm{H}_{3} \mathrm{PO}_{4}+122 \mathrm{H}_{2} \mathrm{O}+16 \mathrm{H}^{+} \rightarrow\left(\mathrm{CH}_{2} \mathrm{O}\right)_{106}\left(\mathrm{NH}_{3}\right)_{16}\left(\mathrm{H}_{3} \mathrm{PO}_{4}\right)+138 \mathrm{O}_{2}$ & 8.625 \\
& Production using $\mathrm{NH}_{4}-\mathrm{N}:$ & \\
2 & $106 \mathrm{CO}_{2}+16 \mathrm{NH}_{3}+\mathrm{H}_{3} \mathrm{PO}_{4}+106 \mathrm{H}_{2} \mathrm{O} \rightarrow\left(\mathrm{CH}_{2} \mathrm{O}\right)_{106}\left(\mathrm{NH}_{3}\right)_{16}\left(\mathrm{H}_{3} \mathrm{PO}_{4}\right)+106 \mathrm{O}_{2}$ & 6.625 \\
& Aerobic remineralization & \\
3 & $\left(\mathrm{CH}_{2} \mathrm{O}\right)_{106}\left(\mathrm{NH}_{3}\right)_{16}\left(\mathrm{H}_{3} \mathrm{PO}_{4}\right)+106 \mathrm{O}_{2} \rightarrow 106 \mathrm{CO}_{2}+16 \mathrm{NH}_{3}+\mathrm{H}_{3} \mathrm{PO}_{4}+106 \mathrm{H}_{2} \mathrm{O}$ & \\
& $\mathrm{Nitrification:}_{4}$ & \\
$4 \mathrm{a}$ & $\mathrm{NH}_{4}^{+}+1.5 \mathrm{O}_{2} \rightarrow \mathrm{NO}_{2}^{-}+2 \mathrm{H}^{+}+\mathrm{H}_{2} \mathrm{O}$ & \\
$4 \mathrm{~b}$ & $\mathrm{NO}_{2}^{-}+0.5 \mathrm{O}_{2} \rightarrow \mathrm{NO}_{3}^{-}$ & 0.5 \\
& $\mathrm{Denitrification:}_{5}$ & - \\
$5 \mathrm{a}$ & $\left(\mathrm{CH}_{2} \mathrm{O}\right)_{106}\left(\mathrm{NH}_{3}\right)_{16} \mathrm{H}_{3} \mathrm{PO}_{4}+84.8 \mathrm{HNO}_{3} \rightarrow 106 \mathrm{CO}_{2}+42.4 \mathrm{~N}_{2}+148.4 \mathrm{H}_{2} \mathrm{O}+16 \mathrm{NH}_{3}+\mathrm{H}_{3} \mathrm{PO}_{4}$ & - \\
$5 \mathrm{~b}$ & $1 / 2 \mathrm{CH}_{2} \mathrm{O}+\mathrm{NO}_{3}^{-} \rightarrow \mathrm{NO}_{2}^{-}+1 / 2 \mathrm{H}_{2} \mathrm{O}+1 / 2 \mathrm{CO}_{2}$ & - \\
$5 \mathrm{c}$ & $3 / 4 \mathrm{CH}_{2} \mathrm{O}+\mathrm{H}^{+}+\mathrm{NO}_{2}^{-} \rightarrow 1 / 2 \mathrm{~N}_{2}+5 / 4 \mathrm{H}_{2} \mathrm{O}+3 / 4 \mathrm{CO}_{2}-$ & \\
& $\mathrm{Anammox}$ & - \\
6 & $\mathrm{NH}_{4}^{+}+\mathrm{NO}_{2}^{-} \rightarrow \mathrm{N}_{2}+2 \mathrm{H}_{2} \mathrm{O}$ & - \\
\hline
\end{tabular}

such as Michaelis-Menten type kinetics (e.g. Sohma et al., 2008). Many models simulate the remineralization of sinking organic matter throughout the water column without explicitly including the organisms involved (e.g. Grégoire and Lacroix, 2001). Including the role of bacteria in models explicitly, such as in the Tuchkovenko and Lonin (2003) model, allows consideration of how non-uniform spatial distribution of bacterial biomass affects biogeochemical oxidation of organic matter, nutrient regeneration and oxygen consumption.

When oxygen is low in the water column, major changes in biogeochemical cycles occur and respiration becomes sequentially based on nitrate, manganese and iron (hydr)oxides and sulphates as observed in permanent or quasi-permanent suboxic-anoxic systems such as the Cariaco Trench, Baltic Sea and Black Sea. Denitrification, the process by which bacteria use nitrate instead of oxygen as an oxidant of organic matter (Table 1, Eq. 5a-c) is probably the single most important suboxic respiratory pathway in the water column. Metal oxide solubility and residence times substantially limit the role of metal reduction in the water column. Model studies dealing with water column redox processes are limited compared to recent advances in the modeling of redox cycling in marine sediments. Only few models include, in addition to the water column biogeochemical processes related to oxygen consumption, the cycling of the main elements in the pelagic redox layer of suboxic-anoxic conditions. For example, Yakushev et al. (2007) configured such a model for the Baltic and Black Seas whereas Oguz et al. (2000), Konovalov et al. (2006), and Grégoire et al. (2008) proposed similar models for the Black Sea interior basin. In general, these models simulate the basic vertical structural features that characterize the water column redox interfaces in these regions reasonably well. These models have comparable biogeochemical complexity including the production and decay of organic matter, and reduction and oxidation of nitrogen, sulfur, manganese, and iron species. Only in the model of Gregoire et al. (2008), biogeochemical processes in anaerobic water were modeled lumping together all the reduced substances in one state variable, similar to the approach used in the modeling of diagenetic processes in the sediments (Soetaert et al., 1996). The cycles of these substances were modeled explicitly in the other models. None of these models explicitly include the anaerobic anammox process (Table 1, Eq. 6) which also removes fixed $\mathrm{N}$ from the water column. Conditions for anammox are rather unique, requiring an environment with a supply of $\mathrm{NH}_{4}^{+}, \mathrm{NO}_{2}^{-}$and low oxygen.

Oxygen is also consumed in the water column by nitrification, the bacterial transformation of ammonium to nitrite and nitrate (Table 1, Eq. 4a and b). The depth distribution of nitrification is tied to the supply of ammonium from decomposition of organic matter and excretion by plankton groups, and is restricted to very low light regions due to light inhibition of nitrifying bacteria (Olson, 1981). In most models, the nitrification process is parameterized as a direct conversion of ammonium into nitrate without the intermediate step of nitrite formation (e.g. Grégoire and Lacroix, 2001). Nitrification can be modelled as a simple first order process $a f\left(\mathrm{O}_{2}\right) \mathrm{NH}_{4}^{+}$, where $a$ is the maximum nitrification rate and $f\left(\mathrm{O}_{2}\right)$ is a non-dimensional function of dissolved oxygen concentration representing the tolerance of nitrifying bacteria to oxygen and can be represented by Michaelis-MentenMonod kinetics (Oguz et al., 2000; Yakushev and Neretin, 
1997). During nitrification a small fraction of the ammonium is converted to $\mathrm{N}_{2} \mathrm{O}$ by bacteria. Under low oxygen conditions, $\mathrm{N}_{2} \mathrm{O}$ is also formed during denitrification, as it represents an intermediate product during the reduction of $\mathrm{NO}_{3}^{-}$to $\mathrm{N}_{2}$. The relative importance of these two production pathways is still debated, but it appears as if the majority of the $\mathrm{N}_{2} \mathrm{O}$ in the ocean is formed by nitrification (Yoshinari, 1976). At present because of continuing uncertainties concerning the formative pathways quantitative global predictions of $\mathrm{N}_{2} \mathrm{O}$ production are not possible (Naqvi et al., 2009). Suntharalingam et al. (2000) developed a simple source function which models $\mathrm{N}_{2} \mathrm{O}$ production as a function of organic matter remineralization and oxygen concentration. Similarly, Nevison et al. (2003) derived a parameterization for the instantaneous production of $\mathrm{N}_{2} \mathrm{O}$ per mole of $\mathrm{O}_{2}$ consumed as a nonlinear function of $\mathrm{O}_{2}$ and depth. The parameterization is based on laboratory and oceanic data and is designed for use in ocean biogeochemistry models.

\subsubsection{Sediment oxygen demand}

Consumption of oxygen in the sediments can greatly exceed its consumption in the water column, especially in shallow waters (Eldridge and Morse, 2008; Sohma et al., 2008). Out of several mechanisms by which oxygen is transported into sediments, mechanistic models commonly consider two: molecular diffusion and bioirrigation (Meile and Van Cappellen, 2003; Meysman et al., 2006). Molecular diffusion flux, $J_{\text {dif }}$, is typically calculated from 1-D oxygen concentration profiles using Fick's law

$J_{\mathrm{dif}}=-\varphi D \frac{d \mathrm{O}_{2}}{d z}$

from known or assumed porosity $(\varphi)$, diffusion coefficients $(D)$ corrected for sediment temperature and tortuosity (Boudreau, 1997) and the oxygen concentration gradients $\left(d \mathrm{O}_{2} / d z\right)$. The oxygen concentration profiles in this calculation may be measured, simulated, or analytically derived (e.g. Cai and Sayles, 1996; Epping and Helder, 1997). Diffusive fluxes, however, often fall short of the directly measured oxygen uptakes (e.g. Silverberg et al., 1987) because bioirrigation, which is generally not a diffusive process, accounts for 40-60\% of the total oxygen flux into the sediment. Bioirrigation is three-dimensional, hence its rates cannot be inferred from one-dimensional microprobe profiles, as those miss the oxygen supplied through animal burrows with great probability ( $>90 \%$ ) (Furukawa et al., 2000). Bioirrigation is typically represented in models as a non-local exchange of porewater with the overlying water, affecting the concentration of sediment solutes at a rate of $\alpha_{\text {irr }}(z)\left(C(z)-C_{0}\right)$, where $C$ and $C_{0}$ are the solute concentrations, respectively, at depth $z$ within the sediment and in the overlying water, and $\alpha_{\text {irr }}(z)$ is a depth-dependent bioirrigation coefficient. The values of the bioirrigation coefficients and their depth dependences are poorly constrained, and their responses to oxygen depletion are more often guessed than measured (see below).
Spatially continuous models often distinguish between the direct oxygen consumption by benthic respiration and the consumption by the reduced chemical products of anaerobic metabolisms (Fig. 4). In the upper sediment layer, where oxygen is consumed primarily by the direct respiration of benthic macro- and micro-fauna, consumption rates are described by the Monod kinetics with a half-saturation constant between 1 and $8 \mu \mathrm{M}-\mathrm{O}_{2}$ (e.g. Katsev et al., 2007). The model of Benoit et al. (2006) considered this layer only, arguing that the reduced solutes, such as $\mathrm{Fe}^{2+}$ and $\mathrm{HS}^{-}$, precipitate in the reduced sediment without contributing to the sediment oxygen demand (SOD). Most commonly, however, contributions of the secondary metabolic products, such as hydrogen sulfide, are taken into consideration. The reduced species are produced in the sediment below the depth of oxygen penetration (OPD), transported upwards by molecular diffusion and the actions of benthic organisms, become oxidized primarily around the OPD, and contribute between 30\% and $80 \%$ of the total SOD (e.g. Soetaert et al., 1996). When detailed information about the anaerobic metabolic pathways is not required, the reduced solutes can be conveniently represented by their effective concentrations known as oxygen demand units (ODU) (Soetaert and Middelburg, 2009; Sohma et al., 2008). This approach simplifies keeping track of oxygen budgets.

Ultimately, SOD is determined either by the rates at which oxygen can be transported into the sediment (transport) or the rates at which it can be consumed within the sediment (reaction). It is therefore not surprising that reaction-transport models indicate that the SOD is sensitive predominantly to the sedimentation flux of organic matter, the intensity of bioirrigation, and the oxygen concentration in the overlying water (Morse and Eldridge, 2007; Katsev et al., 2007). The transport rate depends on the oxygen concentration gradients near the sediment-water interface, and the consumption of oxygen relies predominantly on organic carbon as a terminal electron donor. Sediment temperature, which regulates the rates of microbial metabolisms, is another control factor (Rowe, 2001).

Given the relatively small number of control parameters, statistical parameterizations of the SOD may be possible, but parameterizations thus far rarely included more than two variables. For example, Heip et al. (1995) parameterized the SOD as an exponential function of water depth, assuming that the water depth is a sufficiently good predictor for the deposition flux of organic carbon. Such parameterizations, however, cannot account for the variations in bioirrigation rates. As a compromise between statistical empirical models and mechanistic, site-specific reaction-transport models, Borsuk et al. (2001) suggested a Bayesian approach that is based on a hierarchy of globally-common and site-specific parameters and could improve the accuracy of model predictions. However, despite the advantages that the Bayesian models offer, they have not yet gained popularity because of the complexity of their implementation. 


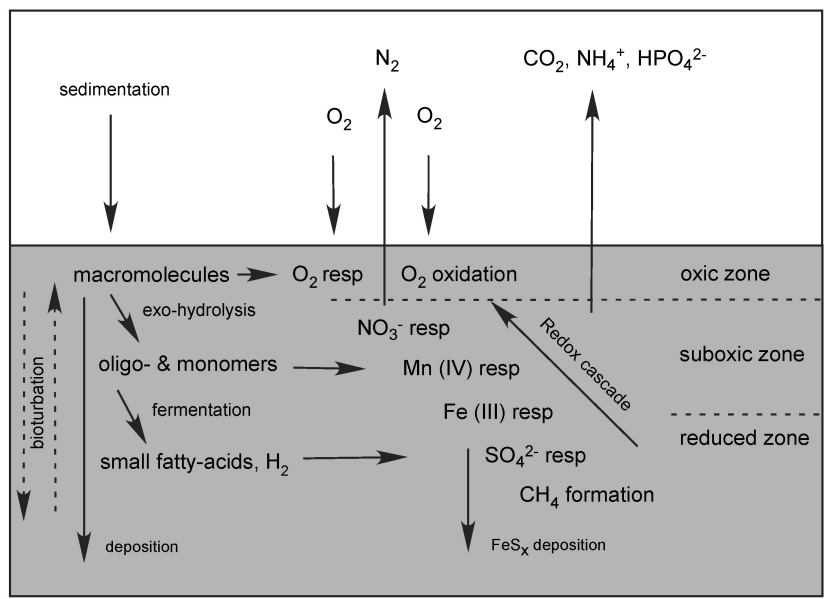

Fig. 4. Schematic presentation of some important diagenetic processes in marine sediments (after Glud, 2008).

Temporal variations in the SOD (see section on transient diagenesis below) generally cannot be addressed through statistical parameterizations, and time-dependent simulations typically have to be tailored to a specific site. SOD can fluctuate diurnally, due to the production of oxygen by benthic photosynthesis (Sohma et al., 2008; Rowe, 2001), seasonally, due to the depletion of oxygen and higher primary productivity in the water column (Eldridge and Morse, 2008), and interannually, in response to external nutrient inputs and other factors (Katsev et al., 2007). Bioirrigation rates may vary between the beginning, the peak, and the end of the hypoxic period (Eldridge and Morse, 2008). SOD also varies spatially. Using a spatially explicit model for Tokyo Bay, Sohma et al. (2008) showed that the central bay and the tidal flats were connected in terms of the oxygen sinks and sources and were interdependent. Because shallow and deep areas can differ substantially in terms of their benthic ecosystems, the study argued for considering such ecosystems separately.

\subsection{Dynamic coupling between sediment and water column}

Coupling between the model's sediment and water column compartments can be an important consideration for the dynamics of nutrient and carbon cycling. The availability of fixed $\mathrm{N}$, for example, is strongly affected by sediment denitrification (Fennel et al., 2006) and primary production may be stimulated when increased sediment denitrification causes $\mathrm{NO}_{3}^{-}$to be removed as $\mathrm{NH}_{4}^{+}$instead of $\mathrm{N}_{2}$ (Kemp et al., 2005). Anoxic bottom waters often lead to the remobilization of sediment phosphorus, which, in turn, may foster eutrophic conditions and anoxia (Wallmann, 2003). Stand-alone diagenetic models often neglect such feedbacks altogether by imposing the solute concentrations and sedimentation fluxes at the sediment water interface (Morse and Eldridge, 2007), or crudely take it into account by using fixed "recycling coeffi- cients" that relate sediment nutrient effluxes to the sedimentation fluxes of organic carbon (Katsev et al., 2006b, 2007). Soetaert et al. (2000) suggested that the optimum approach is to include the evolution of sedimentary particulate matter in model solution and parameterize bottom fluxes of dissolved constituents based on mass budget considerations. Some coupled benthic-pelagic models followed this approach, e.g. Luff and Moll (2004), but most diagenetic models still have room for improvement in this respect. Some coupled models considered oxygen demand only in their lowermost compartment, i.e. either the sediment (Benoit et al., 2006) or a combined bottom-water and sediment layer (Justić et al., 2002). This approach is potentially misleading, as oxygen demand in the lower water column can be not only substantial but also out of phase with the oxygen demand in the sediment. In the Gulf of Mexico, for example, simulations suggest that the SOD contributes between $22 \%$ and $73 \%$ of the total oxygen consumption in the lower water column (Bierman et al., 1994). In addition, during seasonal hypoxia, the locus of oxygen consumption may shift upwards, from the sediment into the water column (Eldridge and Morse, 2008).

\section{Transient adjustment versus steady state dynamics}

For the lack of data, mechanistic models sometimes resort to calibrations at steady-state, after which transient behaviors are simulated using temporal variations in a few selected parameters, such as the bottom water oxygen concentrations or sedimentation fluxes of organic carbon (Eldridge and Morse, 2008; Katsev et al., 2007). The steady state assumption, however, needs to be treated with caution. Certain components of aquatic systems evolve over times much greater than the typical time scales of interest (months to years), and cannot be considered in steady state. For example, Katsev et al. (2007) found that sediments in the Lower St. Lawrence Estuary approached steady state on a time scale of several centuries and, even on a decadal time scale, sediment effluxes differed substantially from their steady-state values. Temporal geochemical responses of sediments to hypoxia typically mimic the thermodynamic sequence of organic carbon mineralization (Middelburg and Levin, 2009): effluxes of Mn and Fe increase (Pakhomova et al., 2007), and sulfides accumulate within the sediment (Fig. 5). Denitrification rates vary insignificantly, and oxic respiration is replaced primarily by sulfate reduction (Middelburg et al., 1996; Katsev et al., 2007). The timing of these changes is often important, especially when changes in the sediment effluxes have to be matched to changes in the water column components. Effluxes of sediment nutrients almost always lag behind changes in the water column conditions. For example, during seasonal hypoxia, the sediment effluxes of metabolites, such as $\mathrm{NH}_{4}^{+}$, lag behind their sediment production by several weeks (Eldridge and Morse, 2008). Lags can also be expected upon the restoration of oxic conditions: for 

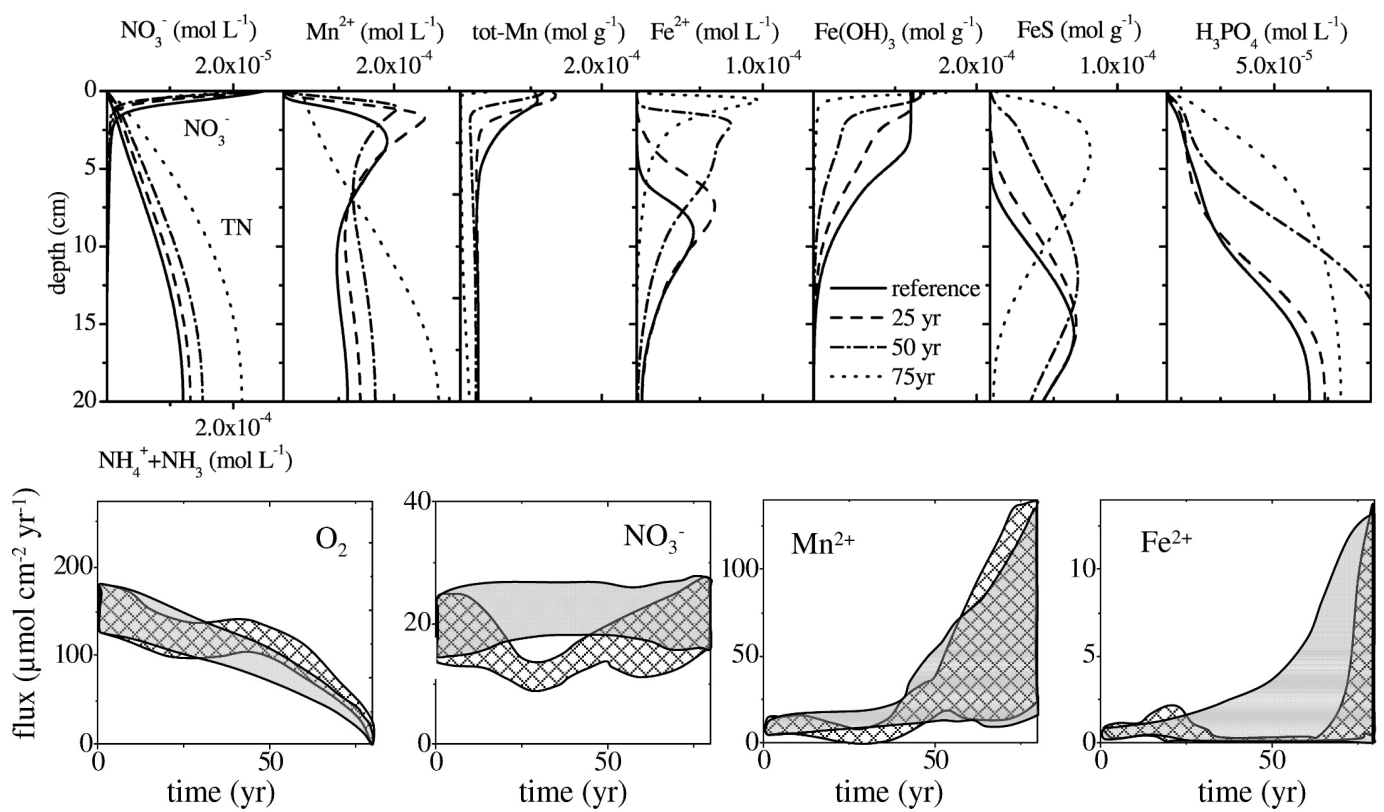

Fig. 5. Top: time evolution of sediment composition, as simulated in the Lower St. Lawrence Estuary by projecting the $1 \mu \mathrm{M}$ per year decline in bottom water $\mathrm{O}_{2}$ levels to complete anoxia (at $t=80$ years). Bottom: prediction uncertainties for sediment-water exchange fluxes (into the sediment for oxygen and nitrate and out of the sediment for $\mathrm{Mn}$ and $\mathrm{Fe}$ ). The solid outlines assume a gradual decrease in bioturbation and bioirrigation, whereas hatched outlines correspond to a threshold-type cessation of bioturbation activities at about $60 \mu \mathrm{M}$ oxygen level. Adapted from Katsev et al. (2007).

example, recovery of nitrifying bacteria from anoxia can take weeks to months (Kemp et al., 2005).

Whether a particular process can be treated as being in steady state or must be treated as transient can often be inferred from simple time scale considerations. For example, solute concentrations in sediment porewater are known to respond to environmental changes relatively fast, and the concentrations of nitrate, phosphate, and other solutes may strongly vary throughout the year. The time that it takes for changes at the sediment-water interface to propagate into the deep sediment, however, may be substantial. Below the depth of bioirrigation (or in the absence thereof), the characteristic time scale of solute transport by molecular diffusion is given by the Einstein's formula: $\tau=x^{2} /(2 D)$, where $x$ is the spatial scale and $D$ is the diffusion coefficient. For typical sediment solutes, $D$ is on the order of $400 \mathrm{~cm}^{2} / \mathrm{yr}$. (It varies somewhat with temperature and also depends on the structure of the sediment solid matrix; for approximations and tabulations, see e.g. Boudreau, 1997.) Thus, for a disturbance to propagate from the sediment surface throughout the diagenetically active sediment layer $(\sim 20 \mathrm{~cm}$ depth) would require $\tau=20^{2} /(2 \cdot 400)=0.5$ years. The distributions of solutes in the sediment porewater therefore may be considered to be approximately in steady state for decadal responses, but generally may not be treated as such for seasonal dynamics. The vertical distributions of sediment solids reach steady state on yet longer times. For a typical sediment burial rate of $0.25 \mathrm{~cm} / \mathrm{yr}$ in coastal sediments, it takes the deposited solid phases $\tau=20 / 0.25=80$ years to traverse the diagenetically active zone. This slow rate of redistribution, on the other hand, allows treating the sediment solid phases as being in steady state when considering fast seasonal dynamics (with notable exception of phases whose dissolution kinetics are fast and depend on the porewater redox potential or the $\mathrm{pH}$, such as the case for some iron oxyhydroxides). Short-term (e.g. seasonal) sediment-water fluxes may be strongly affected by the variations in the amount and reactivity of organic matter whose decomposition takes place in the sediment surface layer. Whereas organic matter buried below the bioturbation zone is typically mineralized over decades and centuries, the organic material freshly deposited in shallow waters is typically characterized by the first-order reaction constants on the order of 1-100 $\mathrm{yr}^{-1}$, i.e. its mineralization occurs in days or months. Events such as algal blooms therefore have the potential of affecting the surficial sediment geochemistry and the sediment-water exchange fluxes within weeks after the organic material reaches the seafloor. The time scales on which the depletion of oxygen during intermittent hypoxia affects benthic macrofauna are discussed below in the section on benthic organisms.

In the water column, the characteristic time scale of adjustment depends on the turnover time for the element of interest. The concentration of a productivity-limiting nutrient, which cycles through the system seasonally, can be expected to change rapidly and respond to seasonal perturbations. The concentrations of refractory elements might respond over 
times close to the hydraulic residence time of water. Importantly, substantial internal cycling of an element between the sediments and the water column can greatly increase its response time to external influences, delaying responses to changes in the external nutrient inputs or remediation (Kemp et al., 2009). For example, in shallow enclosed systems with high sedimentation and release rates of phosphorus, such as in the Baltic Sea, recovery after eutrophication may take hundreds of years (Savchuk and Wulff, 2007). At the onset of anoxia, oxygen can be consumed in the bulk sediment within several days, but re-oxygenation upon the restoration of oxic conditions takes longer, as oxygen supplied from the sediment surface is being consumed by the accumulated reduced substances (Katsev et al., 2006a), delaying recovery (Kemp et al., 2009).

\section{Modeling the effect of hypoxia on biogeochemical cycles and ecosystems}

\subsection{Denitrification and $\mathrm{NH}_{4}^{+}$release}

The effect of hypoxia on nitrogen cycling has global implications. The extent of hypoxia controls the loss of fixed $\mathrm{N}$ in the ocean via denitrification in the water column and marine sediments. Oxygen levels also control the oceanic production of $\mathrm{N}_{2} \mathrm{O}$ which is produced both under suboxic conditions as a byproduct of denitrification and under oxic conditions during nitrification. When transported to the atmosphere, $\mathrm{N}_{2} \mathrm{O}$ can also have global impacts through its effects on radiative forcing and climate. In oceanic waters, nitrate is the most abundant suboxic electron acceptor and thus denitrification is probably the single most important water column suboxic respiratory pathway. Water column denitrification is inhibited at $\mathrm{O}_{2}$ concentrations $>5 \mu \mathrm{M}$ (Codispoti et al., 2001). In most models denitrification is represented by the transformation of nitrate to nitrite to dinitrogen gas (Table 1, Eq. 5ac). Denitrification rates in the water column are described by Michaelis-Menten kinetics as a function of available nitrate and are inhibited by the presence of oxygen (one minus a hyperbolic function) using an oxygen threshold ( $\sim 4$ $6 \mu \mathrm{M}$ ) below which denitrification occurs (e.g. Anderson et al., 2007; Gregoire et al., 2008). Sensitivity analyses have shown that the total and spatial extent of denitrification predicted by models are sensitive to the choice of this oxygen threshold parameter (e.g. Anderson et al., 2007), which is still not very well defined.

The response of the sediment nitrogen cycle to oxygen depletion does not follow a single universal pattern, as both the magnitude and the direction of the net effect depend on the responses of the individual pathways of the cycle. Nitrogen is supplied into the sediment either as particulate $\mathrm{N}$ or dissolved nitrate. Particulate organic $\mathrm{N}$ is returned to the water column upon its mineralization as nitrate, ammonium, or $\mathrm{N}_{2}$ (Middelburg et al., 1996). Similarly to the effects de- scribed below for the phosphorus cycle, the feedbacks between the sediment and water column fluxes of nitrogen can delay the recovery of marine systems from hypoxia (Kemp et al., 2009). Denitrification in the sediment removes the produced nitrate, as well as the nitrate supplied from the overlying water column, and increases the porewater concentrations of ammonium. Because denitrification is energetically less favorable than aerobic mineralization, it is partially inhibited at oxygen concentrations $>0.1-10 \mu \mathrm{M}$. Below these levels, denitrification rates are typically described by Monod kinetics with a half-saturation constant in the range of 1$80 \mu \mathrm{M}$ of $\mathrm{NO}_{3}^{-}$(e.g. Luff and Moll, 2004). Denitrification rates increase with the organic carbon flux but may increase or decrease with oxygen concentration in the bottom water (Middelburg et al., 1996; Morse and Eldridge, 2007; Katsev et al., 2007). Nitrification decreases when the oxygen levels are low, thus hypoxia typically increases $\mathrm{NH}_{4}^{+}$effluxes from sediments (McCarthy et al., 2008). Whereas in oxic sediments oxidation of ammonium makes the sediment a source of nitrate to the overlying waters, hypoxic sediments are typically nitrate sinks (Middelburg et al., 1996).

Several statistical parameterizations for benthic denitrification rates have been suggested. Middelburg et al. (1996) derived a parameterization in terms of organic carbon fluxes and bottom water concentrations of $\mathrm{O}_{2}$ and $\mathrm{NO}_{3}^{-}$. Fennel et al. (2006) suggested a parameterization for estuarine, coastal, and continental shelf regions that links denitrification to the SOD in oxic bottom waters. A subsequent study (Fennel et al., 2009) suggested that the relatively easily measured SOD is a better predictor of sediment denitrification than the interface concentrations of oxygen and nitrate. In shallow regions with strong sediment resuspension, the SOD is also a better predictor than the flux of organic carbon. Whereas in oxic waters denitrification is well correlated with SOD, in hypoxic and anoxic waters parameterizations of denitrification require a combination of mechanistic diagenetic models and measurements (Fennel et al., 2009).

\subsection{Sediment phosphorus re-mobilization and burial efficiency}

Phosphate binding to iron oxides makes sediment phosphorus fluxes sensitive to redox conditions and therefore responsive to carbon loadings and oxygen concentrations. In particular, the release of phosphorus from the sediments when bottom waters become hypoxic is one of the key feedback mechanisms responsible for delayed recoveries from hypoxia in several marine systems (Kemp et al., 2009). Remobilization of phosphorus during hypoxic events occurs in the nearsurface sediment layers when iron oxides become reduced and the released phosphate is transported into the overlying water by either molecular diffusion, sediment resuspension (Eilola et al., 2009), or bioirrigation, with the latter potentially accounting for up to half of the total phosphate efflux (Katsev et al., 2007). To reproduce these dynamics, models 
have to include a number of physical and biogeochemical sediment processes. Phosphate immobilization at the surfaces of ferric iron and other particles is often assumed to be done by adsorption and is simulated as a fast (equilibrium) reversible process. Precipitation of phosphate with ferrous minerals in the reduced sediment and the dissolution of such minerals in the presence of hydrogen sulfide are simulated using effective mineral phases, such as vivianite or fluorapatite (Slomp et al., 1996). The quantitative characterization of such reactions, however, is poorly known, and little kinetic information is available. Despite observations that $\mathrm{C}: \mathrm{P}$ ratios typically increase with depth within the sediment, the organic P pool is often described in sediment models as a fixed fraction of the sediment organic matter (Morse and Eldridge, 2007; Savchuk and Wulff, 2007). At least qualitatively, this effect can be addressed by considering different $\mathrm{C}: \mathrm{P}$ ratios for the reactive and refractory organic model fractions (e.g. Katsev et al., 2007).

In their simulations of the hypoxia in the Baltic Sea, Eilola et al. (2009) parameterized the sediment phosphorus release capacity during hypoxic conditions as a function of oxygen concentration and salinity, whereas under oxic conditions, organic carbon flux was suggested to be a better predictor. Sensitivity analyses from the more detailed reactiontransport models also indicate that $\mathrm{P}$ effluxes depend primarily on the sedimentation fluxes of organic matter and the concentrations of oxygen in the overlying water (e.g. Katsev et al., 2007). In brackish waters, $P$ effluxes may also be affected by the concentration levels of dissolved sulfate relative to the concentrations of dissolved oxygen (e.g. Katsev et al., 2006b).

In seasonally anoxic areas, observations (e.g. see references in Kemp et al., 2005) and model simulations (Krom and Berner, 1981; Eilola et al., 2009) indicate that P mobilizations occur from the top few $\mathrm{cm}$ of the sediment and are controlled by the redox potential. In other instances, the dominant processes may be different. By characterizing P regeneration with a dimensionless Damköhler number, Van Raaphorst et al. (1988) concluded that, whereas high effluxes of $\mathrm{P}$ during the summer were controlled by the processes near the sediment-water interface, low winter fluxes depended more on processes in the anaerobic sediment. On longer time scales, the sediment Fe-oxide layer may become saturated with phosphate, making $\mathrm{P}$ effluxes insensitive to redox conditions (e.g. Eilola et al., 2009). For example, in the decadally hypoxic St. Lawrence Estuary, simulations revealed that $P$ effluxes were insensitive to oxygen concentrations and, consistently, sediment incubations revealed significant $\mathrm{P}$ effluxes even into the oxic waters (Katsev et al., 2007). Spatial variability may also be important. In the seasonally hypoxic Tokyo Bay, the model of Eilola et al. (2009) showed that, as the size of the hypoxic area fluctuated about its average value, the sediment switched between being a sink or a source of $\mathrm{P}$.

\subsection{Food web interactions}

Hypoxia may have profound impacts on trophic interactions through its direct mortality effect on mobile species and benthic organisms, or as a result of indirect effects such as habitat loss and physiological stress that may alter prey-predator interactions. There are few models that specifically address the effect of hypoxia on a marine ecosystem. This is not surprising given the complexity of marine ecosystems and the major challenges that still remain to represent multiple trophic levels and functional groups in ecosystem models. Nevertheless, ecosystem models have been useful for quantifying the influence of hypoxia on food web dynamics, changes in nutrients composition and size of suitable habitat. One way to deal with the level of complexity is to identify key organisms and processes that need to be represented in the specific application, versus those that can be grouped or ignored.

Ecosystem models for Chesapeake Bay (Baird and Ulanowicz, 1989), the Kattegat (Pearson and Rosenberg, 1992) and the Neuse River estuary (Baird et al., 2004) show hypoxia-enhanced diversion of energy flows into microbial pathways to the detriment of higher trophic levels. In Chesapeake Bay, there is a predominance of planktonic components with most of the energy flow channelled through the mesozooplankton (Baird and Ulanowicz, 1989). In the Kattegat, the analysis of Pearson and Rosenberg (1992) indicated that most of the energy flows through the benthic components in this system. Thus, intermittent summer hypoxia below the halocline has severe effects on the ecosystem leading to a reduction in macrobenthic organisms. Despite these differences, both modeled systems respond to hypoxia in a similar way by diverting the energy flow towards the microbial pathway.

Hypoxia can change the functional groups that dominate the phytoplankton community through its differential effect on the inventories of nitrate and phosphate. Anoxic conditions favor the benthic release of phosphate while suboxic sediments and oxygen-depleted waters remove nitrogen by denitrification. For example, a system lacking nitrogen could favor cyanobacteria, which can fix atmospheric nitrogen. Eilola et al. (2009) model oxygen dynamics, phosphorus cycling and the variability of cyanobacteria blooms in the Baltic Sea using the SCOBI model coupled to a circulation model. They find that a large fraction of the interannual variability of cyanobacteria abundance depends on the concentration of surface layer phosphorus in late winter. Their simulation suggests that a significant fraction of the increase of phosphorus content in the Baltic Sea proper since the early 1970 is explained by the release of phosphorus from increased anoxia area during this period.

Hypoxia may promote the abundance of low-oxygentolerant organisms such as jellyfish. Kolesar (2006) studied the effects of ctenophore predation and competition with fish larvae at varying $\mathrm{O}_{2}$ concentrations in the Chesapeake 
Bay using an individual-based, spatially-explicit food web model of the ctenophore-fish larvae-copepod system. The model simulation suggested that $\mathrm{O}_{2}$ concentration alone does not have a significant effect on ingestion of fish larvae by ctenophores. But increased occurrence of low $\mathrm{O}_{2}$ favored oxygen tolerant ctenophore predators, increased vertical overlap between ctenophores and larval fish resulting in more larval fish predation (i.e. reduction in larval fish abundance). However, one major difficulty in this model is the lack of adequate observational knowledge to develop robust parameterizations for oxygen regulation of growth and survival characteristics.

The spatial and temporal distribution and severity of hypoxia in a coastal system vary according to a combination of environmental factors and, thus, the impacts on living resources also vary. For example, the mortality of living resources is associated with the frequency of hypoxia and its duration, and the horizontal and vertical distributions of organisms depend on the distribution of hypoxic waters. Kremp et al. (2007) used a 3-D ecosystem model to simulate how the oxygen dynamics is affected by inflow events in the Baltic Sea, which occur at irregular intervals of one to ten years and renew the bottom waters of the central Baltic. They found that the extent of hypoxia and suitable habitat volume of calanoid copepods and optimal volume for the reproduction of cod could not be calculated with confidence because they all vary considerably in response to different meteorological data used to force the model. Karim et al. (2002) developed a probabilistic model to calculate the occurrence of oxygen-depleted water and applied this method to a eutrophicated shallow bay in western Japan to investigate the environmental impact of eutrophication on the living resources. They found that this method allowed them to evaluate the spatial and temporal pattern and severity of damage caused by hypoxia on living resources.

\subsection{Effects on benthic organisms, bioturbation, and bioirrigation}

Benthic responses to estuarine, enclosed sea, or open shelf hypoxia depend on the duration, repeatability, and intensity of oxygen depletion, and on whether $\mathrm{H}_{2} \mathrm{~S}$ is formed (Levin et al., 2009). In environments such as the OMZ, benthic fauna can be adapted to $\mathrm{O}_{2}$ levels as low as $\sim 5 \mu \mathrm{M}$ (Diaz and Rosenberg, 2008), which indicates that low oxygen levels do not automatically result in low benthic activities. In recently hypoxic areas, however, dissolved oxygen concentrations below $\sim 20 \mu \mathrm{M}$ cause mass mortality and cessation of bioturbation (Diaz and Rosenberg, 2008; Kemp et al., 2005). Production of $\mathrm{HS}^{-}$in the reduced sediment layers tends to eliminate deeper-dwelling species (Aller, 1994), decreasing the depth of bioturbation. Sediments become recolonized when oxygen levels recover, but recolonization takes time and the responses of benthic communities exhibits a hysteresis (Diaz and Rosenberg, 2008). The early colonists are typ- ically smaller organisms. Because bioturbation scales with body size (Meysman et al., 2003), they bioturbate to a shallower depth and with lower intensity than the pre-hypoxia macrofauna (Levin et al., 2009). The temporal dynamics of benthic responses may vary by species. Whereas the number of studies dedicated to the ecology of intermittently hypoxic sediments has increased substantially in recent years, few of those studies resulted in quantitative parameterizations of bioturbation and bioirrigation dynamics.

Relationships between macrofauna diversity and the sediment-water exchange fluxes are highly complex (Middelburg and Levin, 2009) and understudied. Biological studies tend to focus on the effects of hypoxia on biological communities and such characteristics as diversity, biomass, and population densities. Geochemical studies, on the other hand, are concerned with the area-averaged chemical fluxes and therefore rely on the effective parameterizations of bioturbation and bioirrigation rates. The distinction between the effects on communities and the effects on rates is important. So far, relatively few efforts have been dedicated to quantifying how oxygen depletion affects the rates of solute and solid phase transports by benthic organisms. Sediment models have to rely on the assumed, rather than measured, relationships between the bioirrigation/bioturbation coefficients and the sediment-water interface oxygen concentration. Suggested parameterizations ranged from linear (Fossing et al., 2004; Morse and Eldridge, 2007) to strongly nonlinear (Ritter and Montagna, 1999), to threshold-type (Wallmann, 2003). For example, Eldridge and Morse (2008) consider bioirrigation coefficients that scale linearly with $\mathrm{O}_{2}$ concentrations recorded at $1 \mathrm{~mm}$ below the sediment surface, whereas Wallmann (2003) assumed that bioturbation decreases rapidly when the oxygen concentration drops below $20 \mu \mathrm{M}$. Comparison of gradual vs. threshold-type responses (Katsev et al., 2007) reveals that the choice of this approximation is one of the most significant determining factors for the benthic fluxes predicted by the model. Because different types of organisms are affected by hypoxia in different ways, it appears advantageous to consider different organism groups separately. Archer et al. (2002) differentiated between the responses of bioturbators and bioirrigators: for bioturbation, they assumed a Monod-type decrease with a half-saturation constant $20 \mu \mathrm{M}-\mathrm{O}_{2}$, whereas the bioirrigation intensity was assumed, following the observations of Reimers et al. (1992), to have a maximum value at around $8 \mu \mathrm{M}-\mathrm{O}_{2}$. Sohma et al. (2008) used a coupled diagenetic-ecological model and distinguished between suspension feeders and deposit feeders. The study parameterized bioturbation and bioirrigation coefficients as hyperbolic functions of the organism densities and treated the consumption and production of living organisms explicitly. 


\section{Case studies}

Because hypoxia occurs on a variety of environments, models differ significantly in their complexity and temporal and spatial resolution (Table 2). In coastal regions, eutrophication acts as an enhancing factor to hypoxia and anoxia and, when coupled with adverse physical conditions, can increase the frequency and severity of hypoxia. The importance of developing predictive models of nutrients, primary production and $\mathrm{O}_{2}$ concentrations in estuarine regions has long been recognized for their utility in evaluating the potential effectiveness of nutrient management strategies designed to reduce hypoxia. In comparison, efforts to simulate water column biogeochemical cycles in suboxic and anoxic conditions are mostly confined to permanent hypoxia regions. Recently, concerns that ocean warming and increased stratification of the upper ocean caused by climate change will likely reduce oxygen concentrations have stressed the importance of developing models that couple realistic physics and biogeochemistry at adequate scale.

\subsection{Northern Gulf of Mexico}

The largest zone of oxygen-depleted coastal waters in the western Atlantic Ocean is in the Mississippi River discharge region of the northern Gulf of Mexico (NGOM). A range of modeling approaches, from simple to complex, have contributed to a better understanding of the factors influencing hypoxia in the Mississippi River plume region. Turner et al. (2006) used a purely empirical approach, fitting simple and multiple linear regression models of hypoxic bottom area against various nutrient loads from the combined Atchafalaya and Mississippi Rivers. They tested different nutrient loading lag times and found the best relationship $\left(r^{2}=0.60\right.$ for total phosphorus) was obtained two months (May) prior to the maximum observed extent of hypoxia (July). By adding the variable "Year" in the multiple regression, they were able to explain even more of the variance $\left(r^{2}=0.82\right)$ by using the nitrite + nitrate loading from the month of May as a predictor of bottom hypoxic area in July. They justified the introduction of the "Year" term by arguing that the storage of organic carbon in the sediment increases with time, thus increasing sediment oxygen demand. In a subsequent study, Turner et al. (2008) investigated the sensitivity of NGOM hypoxia to nitrogen loading and observed that organic matter and nitrogen accumulated in sediment from previous years had increased the potential hypoxia development for a given nitrogen input to the system.

Neglecting cross-shelf exchange processes and assuming that the Mississippi-Atchafalaya freshwater plume can be represented as a river to a first approximation, Scavia et al. (2003) simulated hypoxia in the NGOM using a onedimensional model that is used extensively in simulations of oxygen concentrations in rivers and estuaries (Chapra, 1997). This river model predicts oxygen concentration downstream from point sources of organic matter loads using mass balance equations for oxygen-consuming organic matter, in oxygen equivalents, and dissolved oxygen deficit. This relatively simple, mechanistic model explained $45-55 \%$ of the variability in hypoxic bottom area. In follow-up studies, Donner and Scavia (2007) combined this hypoxia model with a watershed model to assess the impact of precipitation variability in the Mississippi-Atchafalaya River Basin (MARB) on NGOM hypoxia, and Scavia and Donnelly (2007) performed simulations with the goal of proposing $\mathrm{N}$ and $\mathrm{P}$ reduction targets in the MARB to bring back the size of the hypoxic zone to $5000 \mathrm{~km}^{2}$ by 2015 . Variability in climate and ocean dynamics controls much of the interannual variability in hypoxia extent. For example, in the northern Gulf of Mexico, it was shown that the size of the hypoxic zone varies with precipitation (Justić et al., 1996) being significantly larger in wet years than in dry years. Scavia et al. (2003) use a biophysical model to explore the relative influence of nitrogen load and ocean variability on changes in hypoxia. They find that year-to-year variability in oceanographic conditions can significantly mask, in the short term, the effect of reduced nitrogen loads on the size of the hypoxic zone. These model results stress the importance of setting management goals that take into account the long-term consequences of climate variability and change.

There have been several other models dealing with hypoxia in the NGOM. Justić et al. $(1996,2002)$ simulated oxygen dynamics at one location within the hypoxic zone, using a model that has two vertical layers and is forced by meteorological data and nitrogen loading from the MississippiAtchafalaya Rivers. Bierman et al. (1994) simulated the steady-state summertime conditions for the hypoxic area using a three-dimensional mass balance model that takes into account some of the interactions between food web processes, nutrients, and oxygen. The model studies of Justić et al. (2002) suggest that a long-term increase in riverine nutrient fluxes has been responsible for the historical decrease in bottom layer oxygen concentrations in this region Similarly, the Bierman et al. (1994) model indicates that chemical-biological processes appear to be relatively more important than advective-dispersive transport processes in controlling bottom-water dissolved-oxygen dynamics. Eldridge and Morse (2008) used a non steady state data driven numeric benthic-pelagic model to investigate the role of sediment and water column metabolism in the development of hypoxia on the Louisiana shelf. Their model simulations showed the importance of SOD as the primary sink for $\mathrm{O}_{2}$ at the beginning and end of a hypoxic event on the shelf, but once hypoxia had developed the sediments are driven into a more anoxic state, becoming more dependent on sulphate, and metal reduction.

Finally, fully prognostic, primitive equation, 3-D models of ocean physics have recently been employed to gain further insight into the role of buoyancy forcing and stratification for the development of hypoxia in the NGOM. Hetland 
Table 2. Summary of modeling studies performed on systems described in the Case Studies section.

\begin{tabular}{|c|c|c|c|c|c|c|c|c|c|c|}
\hline \multirow[t]{2}{*}{ Area } & \multicolumn{2}{|c|}{ Model Components } & \multicolumn{3}{|c|}{ Physical Model } & \multicolumn{2}{|c|}{ Time scales } & \multicolumn{3}{|c|}{ Processes represented } \\
\hline & Pelagic & Benthic & OD & $1 \mathrm{D}$ & $3 \mathrm{D}$ & Transient & Steady-state & $\begin{array}{c}\text { Semi- } \\
\text { empirical }\end{array}$ & Food web & $\begin{array}{c}\text { Biogeochemical } \\
\text { cycles }\end{array}$ \\
\hline Gulf of Mexico & $\begin{array}{l}2,6,9, \\
13,14, \\
15,26, \\
27,28\end{array}$ & $\begin{array}{l}2,6,9 \\
13,14\end{array}$ & 27 & $\begin{array}{l}6,15 \\
26\end{array}$ & $\begin{array}{c}2,9, \\
13,14, \\
28\end{array}$ & 6,27 & $\begin{array}{c}2,9,14,15, \\
26\end{array}$ & $\begin{array}{l}6,13, \\
14,15, \\
26,27\end{array}$ & 2,9 & 2,6 \\
\hline Black Sea & $\begin{array}{l}10,11, \\
12,16, \\
20,21, \\
29,30\end{array}$ & 11 & & $\begin{array}{l}12,16, \\
20,21, \\
29,30\end{array}$ & 10,11 & 12 & $\begin{array}{c}10,11,16, \\
20,21,29, \\
30\end{array}$ & & $\begin{array}{c}10,11, \\
12,20, \\
30\end{array}$ & $\begin{array}{l}10,11,12,16 \\
20,21,29,30\end{array}$ \\
\hline Baltic Sea & $\begin{array}{c}5,7,17 \\
19,24 \\
30\end{array}$ & $\begin{array}{c}7,17,19 \\
24\end{array}$ & 5 & 17,30 & $\begin{array}{c}7,19 \\
24\end{array}$ & $\begin{array}{c}7,17,19, \\
24\end{array}$ & $5,19,30$ & 5 & $\begin{array}{l}7,17 \\
19,30\end{array}$ & $\begin{array}{c}7,17,19,24 \\
30\end{array}$ \\
\hline OMZ & $\begin{array}{c}1,3,4,8 \\
18,22 \\
23,25 \\
29\end{array}$ & 25 & & 4,29 & $\begin{array}{l}1,3,8, \\
18,22, \\
23,25\end{array}$ & & $\begin{array}{c}1,3,4,8 \\
18,22,23 \\
25,29\end{array}$ & 18,23 & $1,3,22$ & $\begin{array}{c}1,4,22,25 \\
29\end{array}$ \\
\hline
\end{tabular}

1) Anderson et al. (2007); 2) Bierman et al. (1994); 3) Bopp et al. (2002); 4) Canfield (2006); 5) Carlsson et al. (1999); 6) Eldridge and Morse (2008); 7) Eilola et al. (2009); 8) Gnanadesikan et al. (2007); 9) Green et al. (2006); 10) Gregoire and Lacroix (2001); 11) Gregoire and Friedrich (2004); 12) Gregoire et al. (2008); 13) Hagy and Murrell (2007); 14) Hetland and DiMarco (2008); 15) Justic et al. (1996) \& Justic et al. (2002); 16) Konovalov et al. (2006); 17) Kuznetsov et al. (2008); 18) Matear and Hirst (2003); 19) Neumann (2000) \& Neumann et al. (2002); 20) Oguz et al. (2000); 21) Oguz et al. (2001); 22) Oschlies et al. (2008) \& Schmittner et al. (2008); 23) Sarmiento et al. (1998); 24) Savchuk and Wulff (2007) \& Savchuk et al. (2008); 25) Shaffer et al. (2009); 26) Scavia et al. (2003), Doner and Scavia (2007) \& Scavia and Donnelly (2007); 27) Turner et al. (2006, 2008); 28) Wang and Justic (2009); 29) Yakushev and Neretin (1997); 30)Yakushev et al. (2007).

and DiMarco (2008) used the ROMS (Regional Ocean Modeling System) and simplified biogeochemistry. Their simulations show that the freshwater plumes from the Atchafalaya and Mississippi Rivers are often distinct from one another and that both contribute significantly to the development of hypoxia on the shelf (Fig. 6) through their influence on both stratification and nutrient delivery. Wang and Justić (2009) modelled the circulation and stratification of the LouisianaTexas continental shelf using a different physics model, FVCOM (Finite Volume Coastal Ocean Model), as a preliminary step towards the development of a coupled threedimensional model of physics and biogeochemistry for the Mississippi River Plume area.

In the future, with the advent of Earth System models of ever increasing complexity, we may envisage a coupling of atmospheric models with watershed hydrology models, ocean models and sediment diagenesis models. Watershed models of nutrient origin, fate and transport play a key role in the assessment of the most effective remedial measures in order to reduce nitrate and phosphorus loads from rivers. These include the SPARROW (SPAtially Referenced Regression On Watershed attributes) model of Alexander et al. (2008), the SWAT (Soil and Water Assessment Tool) model of Gassman et al. (2007) and the RIVERSTRAHLER model of Billen et al. (2004).

\subsection{Black Sea}

The Black Sea is one of the best studied examples of a highly stratified marginal sea, constituting one of the world's largest stable anoxic basins. The shallower shelf of the Black Sea has been subject to extensive eutrophication since the 1960's while hypoxia in the deep basin is natural and has persisted for much longer periods. During the last decade considerable progress has been made in modeling biogeochemical processes in the oxic/anoxic environment of this region. These models have been useful to test hypotheses of what processes are responsible for the origin and maintenance of the suboxic layer and have contributed to better understanding of the redox reactions taking place across the anoxic interface.

Several important modeling efforts have focused on the Black Sea low-oxygen environment. For example, Yakushev and Neretin (1997) developed a 1-D advective-diffusionreaction model to study chemical transformation in the lowoxygen region of the Arabian Sea and Black Sea. Oxygen dependent cycling of both sulfur and nitrogen was included in the model. Oguz et al. (2001) developed a diagnostic model of redox cycling in the Black Sea suboxic zone with a somewhat different set of redox reactions that includes the manganese cycle. These models were restricted to the redox interface region and were therefore decoupled from euphotic 


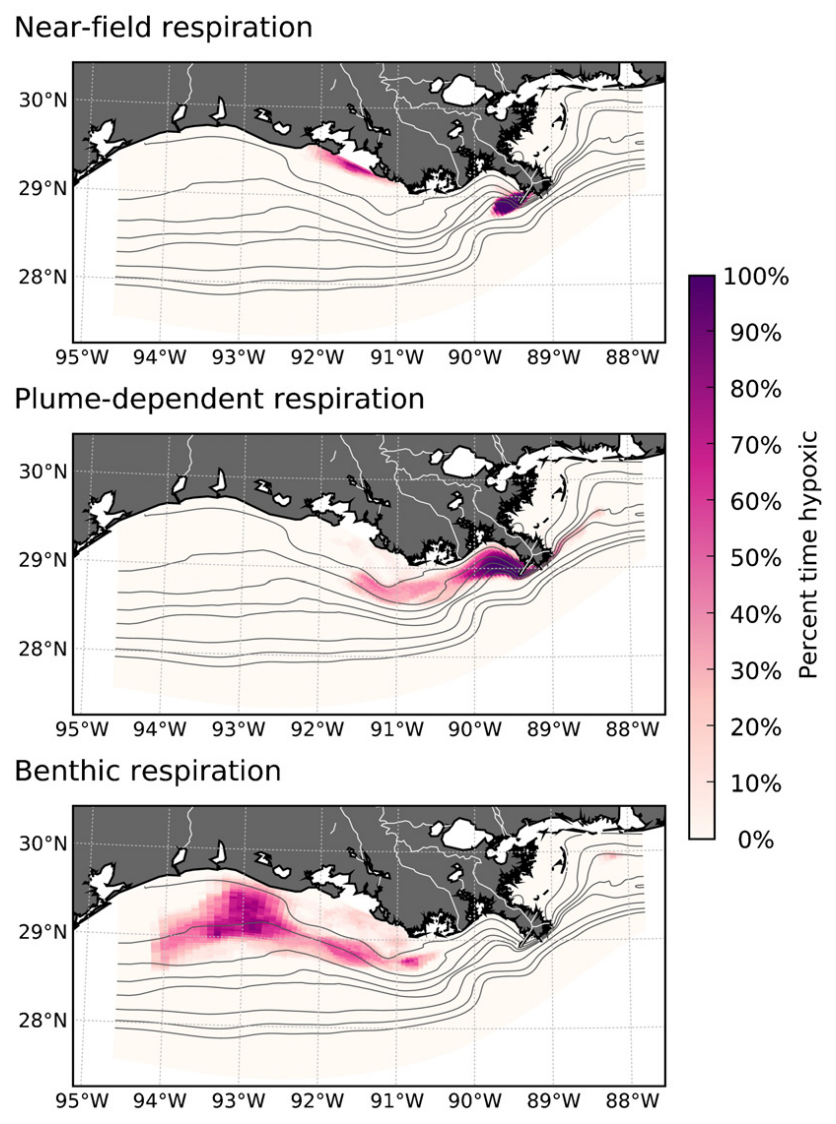

Fig. 6. The three panels show the percentage of time different areas of the Texas-Louisiana continental shelf are affected by hypoxic conditions (less than $60 \mu \mathrm{M}-\mathrm{O}_{2}$ at the bottom) as simulated by three different parameterizations of biological respiration embedded within a realistic hydrodynamic model during August and September (after Hetland and DiMarco, 2008).

zone biological processes. Subsequent efforts, consisted of coupling modules for biological production, nitrogen cycling and redox cycling to a turbulent closure model (Oguz et al., 2000; Konovalov et al., 2006; Yakushev et al., 2007; Gregoire et al., 2008). These models represent a significant advancement in simulating the dynamically-coupled oxic, suboxic and anoxic sytems since both mixing and export production from the overlying euphotic zones as well as regulatory cycling mechanisms within different parts of the water column were components of the modeling scheme. Model results indicate that the position of the upper boundary and thus the thickness of the suboxic layer are controlled by upper layer biological processes (Oguz et al., 2000; Yakushev et al., 2007)

A 1-D hydrophysical-biogeochemical model was developed to study the influence of seasonal variability on the chemical structure of the pelagic redox layer (Yakushev et al., 2007). The model results clearly showed that organic matter, formed during the bloom periods of phytoplankton, exerts a major and direct influence on the structure of the remote redox interface and on the processes occurring in them. As a result, ammonification, nitrification, denitrification and sulfide dominate in the spring and summer, while the oxidation of reduced forms of metals and hydrogen sulfide dominates in winter. Consistent with observations, the simulated oxycline zone coincides with the nitracline where nitrate concentration increases with depth to a maximum value, below which it decreases to zero at the anoxic interface. The increasing concentrations with depth reflect building-up of nitrate as a consequence of the nitrification and nitrogen recycling. Below the nitrate maximum, the decrease with depth is due to denitrification that takes place in two steps with an intermediate nitrite formation as shown in Fig. 7 in the region where nitrate goes to zero. According to the model, $\mathrm{H}_{2} \mathrm{~S}$ was present about 5-10 m below the depth of onset of the increase in $\mathrm{NH}_{4}^{+}$, while maximum absolute values $(1.5 \mu \mathrm{M})$ for $\mathrm{S}^{0}$ occurred at the depth at which $\mathrm{H}_{2} \mathrm{~S}$ appeared. It is important to note that $\mathrm{H}_{2} \mathrm{~S}$ reduces to trace values at deeper levels than the depths at which $\mathrm{O}_{2}$ concentration vanishes. Therefore $\mathrm{H}_{2} \mathrm{~S}$ oxidation was due primarily to the reduction of dissolved manganese that takes place in the region near the anoxic interface; the resulting dissolved manganese diffuses upward from deeper levels to produce particulate manganese. The latter then oxidizes hydrogen sulphide and generates, as a by-product, dissolved manganese that further contributes to maintaining the redox processes in this zone. Elemental sulfur is also produced as a by-product in these processes. The sulfur peak $\left(\mathrm{S}^{0}\right)$ shown in Fig. 7 thus identifies the vertical extent of these redox reactions.

Gregoire et al. (2008) developed a more sophisticated 1D coupled physical-biogeochemical model to simulate the ecosystem of the central Black Sea during the 1988-1992 period when eutrophication and invasion of gelatinous organisms seriously affected the stability and dynamics of the system. The biogeochemical model describes the food web from bacteria to gelatinous carnivores through 24 state variables and explicitly represents processes in the anoxic layer. Biogeochemical processes in anaerobic conditions were represented using an approach similar to that used in the modeling of diagenetic processes in the sediments lumping together all the reduced substances in one state variable (Soetaert et al., 1996). This allows to fully couple processes in the upper oxygenated layer with anaerobic processes in the deep waters, permitting performing long term simulations. The integrated chlorophyll and phytoplankton biomasses, mesozooplankton biomass, depth of oxycline, primary production, bacterial production, surface concentrations of nutrients and plankton simulated by the model and obtained from available data analysis were compared and showed a satisfactory agreement. The model solution exhibits a complex dynamics imparted by the explicit modeling of top predators and shows several years of transient adjustment. 


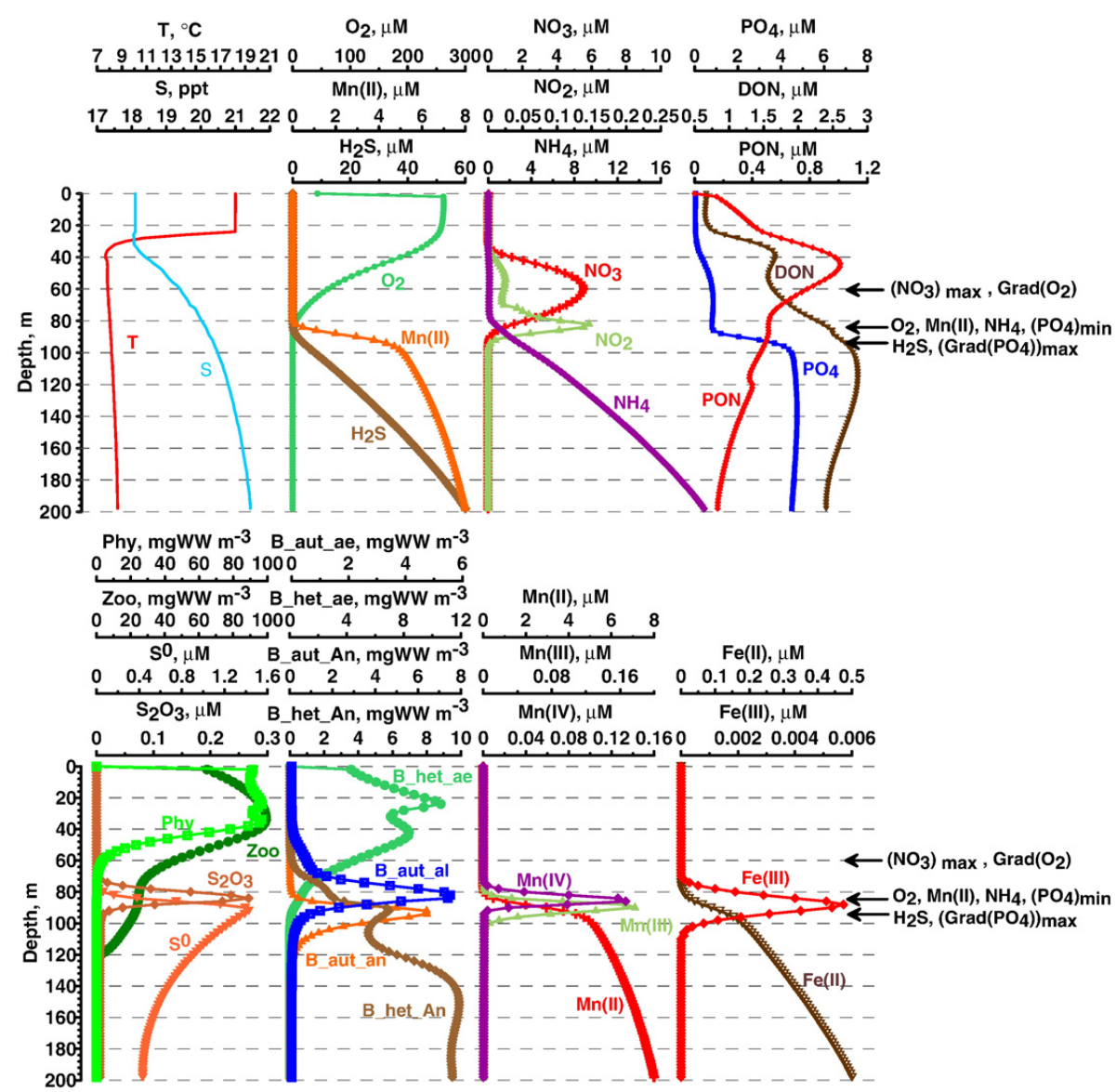

Fig. 7. The vertical distribution of various biogeochemical properties within the water column simulated by the model for summer conditions in the Black Sea (after Yakushev et al., 2007). DON=dissolved organic nitrogen; Phy=phytoplankton; Zoo=zooplankton, B_aut_ae=aerobic autotrophic bacteria; B_het_ae=aerobic heterotrophic bacteria; B_aut_An=anaerobic autotrophic bacteria; B_het_An=anaerobic heterotrophic bacteria; $S^{0}=$ elemental sulfur.

A 3-D model was used by Gregoire and Lacroix (2001) to investigate physical and biogeochemical mechanisms that lead to ventilation of intermediate and deep anoxic waters. They addressed the impact of winter turbulent mixing, frontal instabilities, the exchanges between the north-western shelf and the open sea along the shelf break, remineralization of detritus, and processes of nitrification. The model simulates the space-time variations of the biogeochemical state variables reasonably well. Model results illustrate the seasonal and vertical variations in $\mathrm{O}_{2}$ concentration resulting from its atmospheric and photosynthetic production and consumption due to detritus decomposition, nitrification processes and the oxidation of hydrogen sulfide.

In the northwestern Black Sea shelf region, Grégoire and Friedrich (2004) employed a 3-D coupled biogeochemicalhydrodynamical model to assist the interpretation of benthic observations and to investigate sediment dynamics of the northwestern shelf. Measurements of benthic fluxes (oxygen, nutrients, redox compounds) with in situ flux chambers on the shelf were analyzed. Model results and in situ obser- vations revealed intense benthic recycling and high benthic nutrient fluxes in the nearshore zone and in the northern part of the shelf. This region covers about $\sim 15 \%$ of the shelf area and is connected to the high productivity and high sedimentation caused by riverine input of organic matter. On the outer shelf, covering about $85 \%$ of the shelf area, benthic nutrient regeneration is low due to low productivity. The organic matter is found to be decomposed by aerobic respiration. The sulfate reduction is the main anaerobic pathway in the coastal region, whereas denitrification is more important on the outer shelf. A small amount of organic matter is decomposed by methanogenesis.

\subsection{Baltic Sea}

The Baltic Sea is a semi-enclosed brackish water system, consisting of several connected basins of different depths. The positive water balance of the Baltic implies an estuarine general circulation with pronounced vertical density stratification that prevents mixing and oxygenation of the full water 
column. In the bottom waters of the deep basins, $\mathrm{O}_{2}$ is depleted and hydrogen sulfide occurs frequently. The ecosystem of this region is controlled by physical processes and forced by external input of nutrients. Human activities have increased the loads of nutrients delivered to the Baltic Sea by river runoff and atmospheric input. During the 20th century, nitrogen inputs increased four-fold and phosphorus inputs to the Baltic Sea increased eightfold (Larsson et al., 1985) which led to eutrophication and worsening hypoxia/anoxia. These have stimulated the development of a range of models of different complexity to evaluate the ecosystem response to nutrient load reduction.

A simple semi-empirical management model was developed by Carlsson et al. (1999) to predict seasonal variability in near bottom oxygen concentration in Baltic archipelago areas. Model results show that seasonal variations in $\mathrm{O}_{2}$ could be predicted from water turnover times, organic load and default seasonal patterns for particulate organic matter and temperature. The model can be used to predict the lowest oxygen concentration during the year and to identify coastal areas where low concentrations are likely to appear. A basin-scale box model (SANBALTS, Simple As Necessary Baltic Long-Term Large-Scale) was developed by Savchuk and Wulff (2007) to simulate the interplay between nutrient sources and sink within the seven major basins of the Baltic Sea and to evaluate management options for reducing Baltic Sea eutrophication. The model shows that contemporary nutrient cycles are driven by internal biogeochemical processes in which annual rates are one to two orders of magnitude larger than external inputs and advective transports. Thus, the entire sea would respond slowly to any external perturbations caused either by humans or by climate change, including possible reductions of nutrient loads. Later, Savchuk et al. (2008) used SANBALTS to reconstruct nutrient conditions in the Baltic Sea a century ago. They found that the "pre-industrial" trophic state could have been more phosphorus limited than today because simulated basin-wide annual averages of dissolved inorganic phosphorus concentrations were about $40-80 \%$ of their present day value, while dissolved inorganic nitrogen concentrations were almost the same as today. The biogeochemical mechanism causing the shift towards phosphorus limitation in the model combines higher N:P ratios of the external nutrient inputs with feedbacks in the nutrient cycles. Reduced primary production leads to reduced organic matter sedimentation and oxygen consumption resulting is lower denitrification. In contrast, improved oxygen conditions increased phosphorus removal from the water column and its retention in the sediments.

A coupled 3-D ecosystem-physical model was developed by Neumann (2000) to simulate the nitrogen fluxes of the Baltic Sea. The model includes several nutrients and phytoplankton compartments as well as the process of nitrification, denitrification and nitrogen fixation. In the model, oxygen demand and production is coupled to nitrogen conversion. At the bottom, the model includes a sediment layer, where sink- ing detritus accumulates or can be remineralized. The annual cycle of nitrogen was simulated with a high spatial resolution $(\sim 5.5 \mathrm{~km})$ and compared reasonably well with observations. The model demonstrated the importance of shallow coastal areas for the removal of river borne nitrogen by denitrification in the sediments. In a subsequent study, Neumann et al. (2002) used this coupled ecosystem-circulation to study the response of the model ecosystem to a reduction of riverine nutrient loads. Decadal simulations of the dynamics of the ecosystem of the Baltic Sea were carried out using realistic forcing as a control run and a 50\% reduction of riverine nutrient loads. It was found that the model food web reacts to the load reduction in a complex manner. While the total biomass and nutrients inventories were reduced in the model, there were significant regional differences. In particular, the biomass of diatoms, flagellates and zooplankton decreased while the biomass of cyanobacteria, which can fix atmospheric nitrogen, increased in response to the reduced loads. Comparison of model simulation with observations showed a good representation of the biological cycles in the upper water column and in shallow areas, while the description of the biogeochemical cycles in the near bottom area of the central parts of the Baltic Sea needed further improvements.

A 1-D hydrophysical-biogeochemical model was developed by Yakushev et al. (2007) to study the influence of seasonal variability on the cycling of the main elements in the pelagic redox layer of the Baltic Sea. In the model, the formation and decay of organic matter, the reduction of oxygen to nitrogen, sulfur, manganese and iron species as well as the transformation of phosphorus species were parameterized. The results showed that organic matter formed during phytoplankton bloom periods exerted a major influence on the structure of the redox interface. This was due to competition for $\mathrm{O}_{2}$ between its consumption for oxidation or organic matter originating in the euphotic zone and the consumption for oxidation of reductants supplied from the anoxic deep water.

Recently, Eilola et al. (2009) developed a model SCOBI (Swedish Coastal and Ocean Biogeochemical model) that includes oxygen and phosphorus to investigate the Baltic response to climate variations and anthropogenic activities on long time scales (100 years). The model contains inorganic nutrients, nitrate, ammonium and phosphate, three functional groups of phytoplankton (diatoms, flagellates and cyanobacteria), zooplankton and detritus. The sediments contain nutrients in the form of benthic nitrogen and phosphorus. They show that the SCOBI model coupled to a circulation model is capable of reproducing the main features of phosphorus cycling in the Baltic Sea (Fig. 8). The model, forced by naturally varying freshwater flow and climatological nutrient concentrations, simulates the observed increase and variability of hypoxic areas during the last 30 years (1969-1998) of the modeled period. The results emphasize the importance of internal phosphorus and oxygen dynamics, the variability 

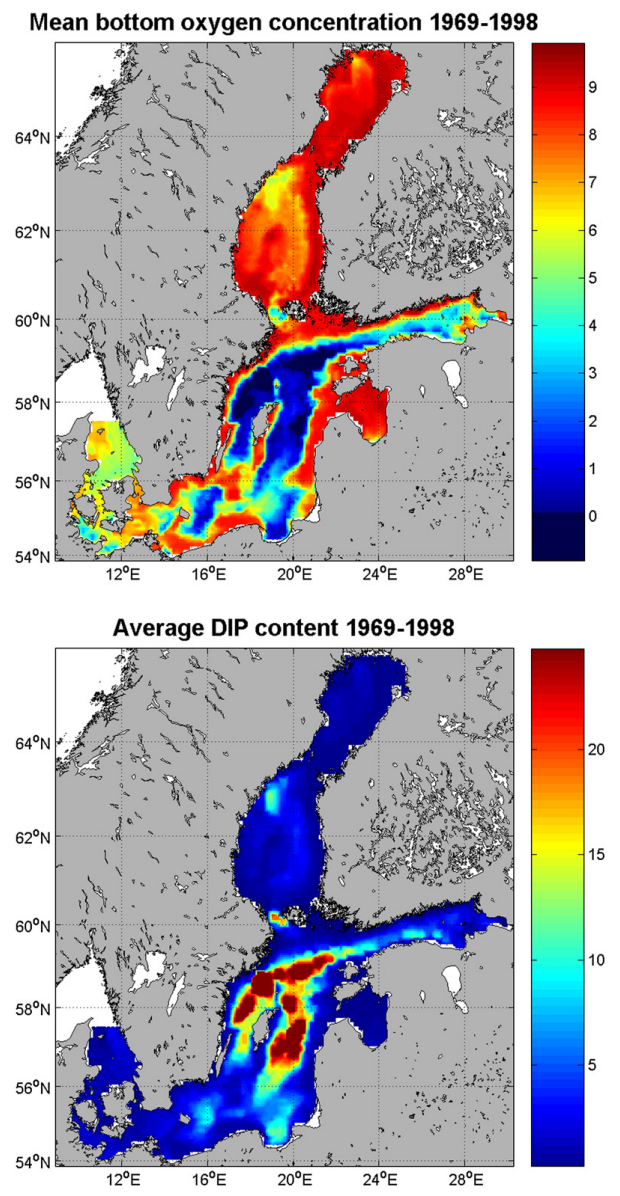

Fig. 8. Modelled mean bottom water oxygen concentration $\left(\mathrm{ml} \mathrm{O}_{2} \mathrm{1}^{-1}\right)$ (upper panel) and vertically integrated dissolved ionorganic phosphorus (DIP) content (ton DIP $\mathrm{km}^{-2}$ ) (lower panel) in the Baltic Sea during 1969-1998 (after Eilola et al., 2009).

of physical conditions and the natural long-term variability of phosphorus supplies from land on the phosphorus content in the Baltic Sea water column.

Bendtsen et al. (2009) modeled the ventilation of bottom waters in the region of the Kattegat using a $k-c$ turbulence closure scheme. Their simulations suggest that bottom waters were less well ventilated in 2002 than in 2001 (about 20 days older in 2002) due to greater stratification in 2002. This led to an extreme hypoxic event in the autumn 2002 in the southern Kattegat. Interruption of anoxia by advection of oxygenated North Sea water into the Baltic Sea anoxic basins results in a cascade of reactions with consequences for nitrogen cycles, formation of particulate manganese and iron oxides and cycling of phosphorus and sulfur (Yakushev et al., 2007).

\subsection{Oxygen minimum zones}

The largest suboxic and hypoxic water masses are embedded in OMZ and occur at mid depths $(\sim 100-1000 \mathrm{~m})$ over wide

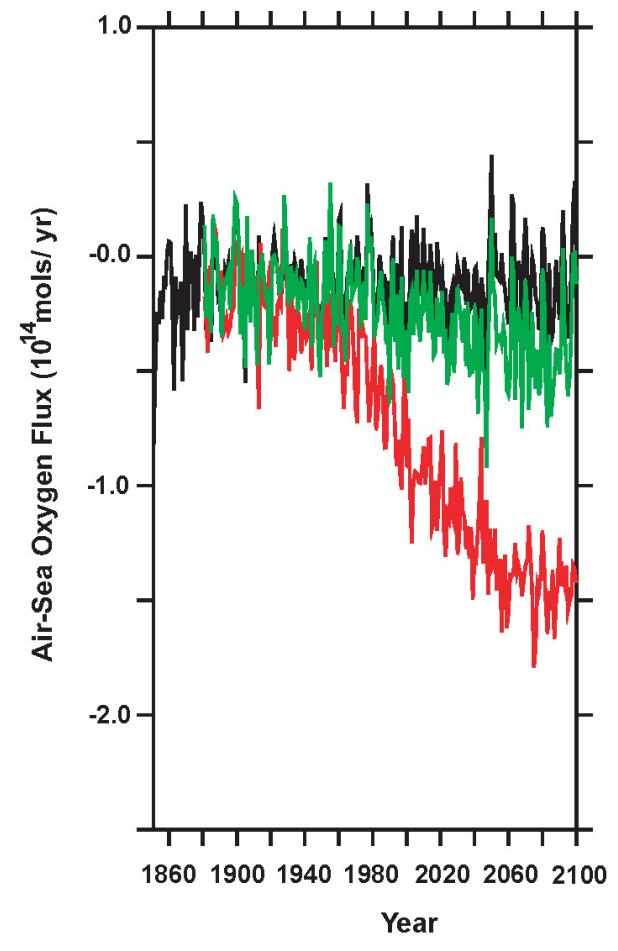

Fig. 9. Global averaged oceanic uptake of oxygen $\left(10^{14} \mathrm{mols} / \mathrm{yr}\right)$. The black line denotes the control experiment with a constant atmospheric level of $\mathrm{CO}_{2}$, the red line denotes the greenhouse forcing experiment using the IS92a radiative scenario, and the green line denotes the control experiment with the solubility of oxygen calculated using the sea surface temperature from the greenhouse gas forcing experiment. Adapted from Matear et al. (2000).

expanses north and south of the equator in the eastern tropical Pacific Ocean and in the northern Indian Ocean (Arabian Sea and Bay of Bengal). In the tropical oceans, Karstensen et al. (2008) showed that OMZ are primarily a consequence of weak ocean ventilation. Oxygen supply to OMZ originates from a surface outcrop area and can also be approximated by the ratio of ocean volume to ventilating flux. These regions play an important role in the global $\mathrm{N}$ cycle being the main areas of nitrogen loss (as $\mathrm{N}_{2}$ and $\mathrm{N}_{2} \mathrm{O}$ ) to the atmosphere through denitrification and anammox process (Codispoti et al., 2001). Thus, OMZ regions are formed by physical and biological phenomena that are dynamic and difficult to model. The proximity of OMZ to coastal upwelling regions suggests that upwelling regions are dynamically linked to the OMZ (Canfield, 2006).

In the Arabian Sea, Anderson et al. (2007) used a 3D hydrodynamic-ecosystem model to examine the factors determining the observed spatio-temporal distribution of denitrification. Oxygen is included in the model as a state variable, but this is restored to observations below the euphotic zone because the resolution of the model was found to be insufficient to reproduce the high gradients of oxygen observed 
above the OMZ which is necessary to accurately model denitrification in the Arabian Sea. The ecosystem model includes cycling of organic matter via detritus and dissolved organic matter. They found detritus was the primary organic substrate consumed in denitrification (97\%) with a small (3\%) contribution by dissolved organic matter. The modeled distribution of denitrification was closely tied to the anoxic zone and showed considerable seasonal variability. The predicted annual dentrification of $26.2 \mathrm{TgNyr}^{-1}$ was similar to other estimates obtained by calculating nitrate deficit and slightly higher than those $\left(11-24 \mathrm{TgNyr}^{-1}\right)$ estimated by Yakushev and Neretin (1997) using a simple model of $\mathrm{N}$ transformation in the water column. Sensitivity analyses indicate that the predicted denitrification depends on the stoichiometry applied, detritus sinking rate, and the value of the critical oxygen concentration.

Global ocean circulation models predict an expansion of $\mathrm{OMZ}$ as well as an overall decline of the dissolved marine oxygen inventory with global warming (Sarmiento et al., 1998; Matear et al., 2000; Bopp et al., 2002; Matear and Hirst, 2003). The loss of oxygen is predicted not just because $\mathrm{O}_{2}$ is less soluble in warmer water but also because of reduced ventilation of the ocean interior. In all of these studies, the predicted rate of oxygen outgassing from the global ocean (Fig. 9) is three to four times faster than one might have predicted from the temperature-dependence of oxygen solubility alone (Garcia and Gordon, 1992). In contrast, based on climate model runs, Gnanadesikan et al. (2007) suggested that waters in the tropical thermocline may, in fact, become younger as a result of reduced upwelling of deep waters under global warming scenarios. They speculated that the reduction in the water age might coincide with local increases in oxygen, contrasting the generally expected decline of the global ocean's oxygen inventory. A possible explanation of this discrepancy is that the complex equatorial current systems which transport oxygen into the tropical OMZ are not adequately represented in coarse resolution climate models (e.g. Oschlies et al., 2008). Early signs of oxygen decrease in tropical OMZ have been detected by Stramma et al. (2008), but this needs to be confirmed by other studies. In fact, due to substantial interannual and interdecadal variability in the models and observations (Deutsch et al., 2005; Garcia et al., 2005; Frölisher et al., 2009), reliable detection of a negative, global, oxygen trend remains a challenge (Gilbert et al., 2009).

In addition to the temperature and circulation driven oxygen decline, biogeochemical responses to climate change are also likely to affect the oceanic oxygen cycle. In this regard, Oschlies et al. (2008) used a global biogeochemical climate model to explore the effect of $p \mathrm{CO}_{2}$-related increase in $\mathrm{C}: \mathrm{N}$ drawdown as observed in mesocosm experiments. For a simulation run from the onset of the industrial revolution until AD 2100 under a "business-as-usual" scenario for anthropogenic $\mathrm{CO}_{2}$ emission, the model predicts a $50 \%$ increase in the suboxic water volume by the end of this century in response to the respiration of excess organic carbon formed at higher $\mathrm{CO}_{2}$ levels. Because most of the oxygen consumed during organic matter remineralization is used to oxidize carbon rather than nitrogen, the enhanced $\mathrm{C}: \mathrm{N}$ ratios then result in excess oxygen consumption at depth. In concert with the increase in the volume of suboxic waters, simulated denitrification rates increase by more than $40 \%$ by the end of this century.

On much longer time scales, Schmittner et al. (2008) presented climate change projections for 2000 years into the future to a continuation of the present emission trends using a coupled, intermediate complexity global model of climate, ecosystems and biogeochemical cycles. Model results show a decrease in subsurface oxygen concentration, tripling the volume of suboxic water and quadrupling the global water column denitrification. The oxygen changes are consistent with earlier 600-year model simulations using a simpler biogeochemical model (Matear and Hirst, 2003). Along the west coast of North America, the model predicts oxygen reductions of $40-80 \%$. Such strong reduction in oxygen concentrations will very likely increase the frequency of hypoxic events on the shelves. Likewise, using an Earth System model with simpler ocean physics but taking into account other biogeochemical processes such as the destabilization of methane hydrates with prolonged global warming, Shaffer et al. (2009) argue that the oxygen decrease will be substantial and last for several thousands of years.

Given the known limitations of coarse-resolution ocean models in simulating today's $\mathrm{O}_{2}$ distribution (e.g. Keeling et al., 2010), the model predictions on all time and space scales are speculative. The simulation of the tropical OMZ is especially challenging because the models do not resolve well the tropical jets relevant to $\mathrm{O}_{2}$ supply. Predicted changes in tropical OMZ are also based on poorly constrained aspects of biogeochemistry, such as dependency of the maximum photosynthetic rate on water temperature (Matear and Hirst, 2003), and the dependency of $\mathrm{C}: \mathrm{N}$ ratios of marine organic matter on $p \mathrm{CO}_{2}$ (Oschlies et al., 2008).

\section{Summary}

- Modeling approaches, from simple to complex, have significantly improved our understanding of hypoxia in many coastal regions. Biogeochemical modeling, in particular, helped improve our understanding of individual processes and their interactions, which is not possible by adopting an empirical approach.

- Region-specific models tend to perform poorly when applied to systems outside of the region for which they were developed, even after re-parameterization. Generic ecological models (e.g. Blauw et al., 2009) on the other hand, have been applied successfully in a range of scenarios studies in coastal regions. 
- Substantial progress has been made towards simulating biogeochemical processes in permanent or quasipermanent hypoxic-anoxic systems. In particular, models have been useful in understanding and directing further studies of the redox cycles of C, N, S, Mn and Fe within the water column and sediments.

- Advances in 3-D coupled physical-chemical-biological models have improved our quantitative understanding of the effects of freshwater discharge on hypoxia development. Sensitivity analyses have permitted to differentiate between the roles of stratification and nutrient load on the extent and duration of hypoxic conditions, contributions that are difficult to evaluate empirically. Uncertainties still exist regarding the temporal and spatial resolution required to simulate possible impacts of future conditions, including local nutrient and organic matter load management scenarios.

- Modeling of the responses of marine ecosystems to hypoxia is still in its infancy, and many problems remain. Virtually all modeling efforts have focused on lower trophic levels, whereas higher trophic levels have been mostly ignored. In some cases, incorporating higher trophic levels may be essential for simulating sinking particle fluxes correctly.

- Overall, the research community recognizes the critical importance of models in studies of hypoxia. We can therefore expect further improvements in the development of models and in their ability to simulate and predict changes in the extent and intensity of hypoxia in both coastal regions and OMZ.

\section{Recommendations for future research}

- Surprisingly, few efforts have been made so far to model OMZ and their adjacent coastal upwelling region even though hypoxia events have been reported in all major upwelling systems, especially those associated with eastern boundary currents.

- Whereas most models describe biogeochemical cycles under the assumption of constant stoichiometric ratios, the stoichiometric relationship between oxygen, carbon and other macro- and micro-nutrients is uncertain and variable. Better understanding is needed of the factors influencing the elemental composition of phytoplankton, remineralization length scale of elements and burial efficiency of organic carbon and nutrients under low oxygen levels.

- To improve coupled sediment-water-column models, better parameterizations are needed for phosphorus release capacity and burial, defined as functions of organic carbon fluxes, oxygen and sulfate concentrations in the overlying water, and Fe(III) availability. Short-term, e.g. seasonal, effects need to be distinguished from long term effects.

- We need to improve characterizations of the bioturbation and bioirrigation responses to hypoxia and the associated changes in sediment geochemistry. Whereas much work has focused on characterizing the responses of benthic biological communities, fewer efforts have been dedicated to characterizing the associated changes in sediment mixing rates.

- Major challenges remain in terms of developing, parameterizing and validating complex biogeochemical/ecosystem models. Perhaps the most immediate need is for more rigorous validation of our models, using independent datasets that quantitatively assess the predictive skill.

- Improving our ability to predict changes in ocean $\mathrm{O}_{2}$ in a warming world will require advances in developing coupled physical-biogeochemical models. A critical need is to improve the representation of water transports influencing OMZ by developing coupled physical/biological ocean general circulation model of sufficient resolution and to include the necessary biogeochemistry. In particular, most climate models do not explicitly accounts for $\mathrm{N}_{2} \mathrm{O}$ production and consumption, a significant shortcoming given the role of $\mathrm{N}_{2} \mathrm{O}$ as a long lived greenhouse gas.

- Recent technological developments offer opportunities to monitor changes in the ocean oxygen regime and to validate predictions of oxygen trend in numeric models. There is a need for collaboration between observationalists and modelers to make the best use of advances in modeling techniques and continuous automated observations of $\mathrm{O}_{2}$ levels and other chemical parameters, as well as continue the development of sensors that can measure the biogeochemical and biological impacts of hypoxia.

Acknowledgements. We thank SCOR for supporting the Working Group 128 on "Natural and Human-Induced Hypoxia and Consequences for Coastal Areas" and all members of this SCOR working group for their contribution. Special thanks to Lizette Beauchemin for a careful literature survey and to William Crawford, Ken Denman, and Jing Zhang whose comments helped to improve this manuscript. Andy Dale and two other anonymous reviewers provided valuable comments on the manuscript.

Edited by: J. Middelburg 


\section{References}

Alexander, R. B., Smith, R. A., Schwarz, G. E., Boyer, E. W., Nolan, J. V., and Brakebill, J. W.: Differences in phosphorus and nitrogen delivery to the Gulf of Mexico from the Mississippi River Basin, Environ. Sci. Technol., 42, 822-830, 2008.

Aller, R. C.: Bioturbation and remineralization of sedimentary organic-matter - effects of redox oscillation, Chem. Geol., 114, 331-345, 1994.

Anderson, T. R., Ryabchenko, V. A., Fasham, M. J. R., and Gorchakov, V. A.: Denitrification in the Arabian Sea: A 3D ecosystem modelling study, Deep-Sea Res. I, 54, 2082-2119, 2007.

Archer, D. E., Morford, J. L., and Emerson, S. R.: A model of suboxic sedimentary diagenesis suitable for automatic tuning and gridded global domains, Global Biogeochem. Cy., 16, 1017, doi:10.1029/2000GB001288, 2002.

Baird, D., Christian, R. R., Peterson, C. H., and Johnson, G. A.: Consequences of hypoxia on estuarine ecosystem function: Energy diversion from consumers to microbes, Ecol. Appl., 14, 805-822, 2004.

Baird, D. and Ulanowicz, R. E.: The seasonal dynamics of the Chesapeake Bay ecosystem, Ecol. Monogr., 59, 329-364, 1989.

Bange, H. W., Rapsomankis, S., and Andrae, M. O.: Nitrous oxide in coastal waters, Global Biogeochem. Cy., 10, 197-207, 1996.

Bendtsen, J., Gustafsson, K. E., Soderkvist, J., and Hansen, J. L. S.: Ventilation of bottom water in the North Sea - Baltic Sea transition zone, J. Marine Syst., 75, 138-149, 2009.

Benoit, P., Gratton, Y., and Mucci, A.: Modeling of dissolved oxygen levels in the bottom waters of the Lower St. Lawrence Estuary: Coupling of benthic and pelagic processes, Mar. Chem., 102, 13-32, 2006.

Bierman, V. J., Hinz, S. C., Dong-Wei, Z., Wiseman, W. J., Rabalais, N. N., and Turner, R. E.: A preliminary mass balance model of primary productivity and dissolved oxygen in the Mississippi River Plume/Inner Gulf Shelf Region, Estuaries, 17, 886-899, 1994.

Billen G., Garnier, J., and Hanset, P.: Modelling phytoplankton development in whole drainage networks: the RIVERSTRAHLER Model applied to the Seine river system, Hydrobiologia, 289, 119-137, 1994.

Blauw, A. N., Hans F. J. L., Bokhorst, M., and Erftemeijer, P. L. A.: GEM: a generic ecological model for estuaries and coastal waters, Hydrobiologia, 618, 175-198, 2009.

Bopp, L., Le Quéré, C., Heimann, M., Manning, A. C., and Monfray, P.: Climate-induced oceanic oxygen fluxes: Implications for the contemporary carbon budget, Global Biogeochem. Cy., 16, 1022, doi:10.1029/2001GB001445, 2002.

Borsuk, M., Higdon, D., Stow, C. A., and Reckhow, K. H.: A Bayesian hierarchical model method to predict benthic oxygen demand from organic matter loading in estuaries and coastal zones, Ecol. Model., 143, 165-181, 2001.

Boudreau, B. P.: Diagenetic Models and their Implementation, Springer-Verlag, Berlin, 1997.

Buesseler, K. O., Lamborg, C. H., Boyd, P. W., Lam, P. J., Trull, T. W., Bidigare, R. R., Bishop, J. K. B., Casciotti, K. L., Dehairs, F., Elskens, M., Honda, M., Karl, D. M., Siegel, D. A., Silver, M. W., Steinberg, D. K., Valdes, J., Van Mooy, B., and Wilson, S.: Revisiting carbon flux through the ocean's twilight zone, Science, 316, 567-570, 2007.
Cai, W. J. and Sayles, F. L: Oxygen penetration depths and fluxes in marine sediments, Mar. Chem., 52, 123-131, 1996.

Canfield, D. E.: Models of oxic respiration, denitrification and sulfate reduction in zones of coastal upwelling, Geochim. Cosmochim. Ac., 70, 5753-5765, 2006.

Carlsson, L., Persson, J., and Håkanson, L.: A management model to predict seasonal variability in oxygen concentration and oxygen consumption in thermally stratified coastal waters, Ecol. Model., 119, 117-134, 1999.

Cerco, C. F. and Cole, T.: Three-dimensional eutrophication model of Chesapeake Bay, J. Environ. Eng., 119, 1006-1025, 1993.

Chapra, S. C.: Surface water quality modeling, Series in Water Resources and Environmental Engineering, McGraw-Hill, New York, USA, 1997.

Cicerone, R. and Oremland, R. S.: Biogeochemical aspects of atmospheric methane, Global Biogeochem. Cy., 2, 229-327, 1988.

Codispoti, L. A., Brandes, J. A., Christensen, J. P., Devol, A. H., Naqvi, S. W. A., Paerl, H. W., and Yoshinary, T.: The oceanic fixed nitrogen and nitrous oxide budgets: moving targets as we enter the anthropocene?, Sci. Mar., 65 (suppl. 2), 85-105, 2001.

D’Avanzo, C. and Kremer, J. N.: Diel oxygen dynamics and anoxic events in an eutrophic estuary of Waquoit Bay, Massachusetts, Estuaries, 171B, 131-139, 1994.

Deutsch, C., Emerson, S., and Thompson, L.: Fingerprints of climate change in North Pacific oxygen, Geophys. Res. Lett., 32, $1-4,2005$.

Diaz, R. J. and Rosenberg, R.: Spreading dead zones and consequences to marine ecosystems, Science, 321, 926-929, 2008.

Doney, S. C., Lindsay, K., Caldeira, K., Campin, J.-C., Drange, H., Dutay, J.-C., Follows, M., Gao, Y., Gnanadesikan, A., Gruber, N., Ishida, A., Joos, F., Madec, G., Maier-Reimer, E., Marshall, J. C., Matear, R. J., Monfray, P., Mouchet, A., Najjar, R., Orr, J. C., Plattner, G.-K., Sarmiento, J., Schlitzer, R., Slater, R., Totterdell, I. J., Weirig, M.-F ., Yamanaka, Y., and Yool, A.: Evaluating global ocean carbon models: The importance of realistic physics, Global Biogeochem. Cy., 18, GB3017, doi:10.1029/2003GB002150, 2004.

Donner, S. D. and Scavia, D.: How climate controls the flux of nitrogen by the Mississippi River and the development of hypoxia in the Gulf of Mexico, Limnol. Oceanogr., 52, 856-861, 2007.

Druon, J.-N., Schrimpf, W., Dobricic, S., and Stips, A.: Comparative assessment of large-scale marine eutrophication: North Sea area and Adriatic Sea as case studies, Mar. Ecol.-Prog. Ser., 272, 1-23, 2004.

Eilola, K., Meier, H. E. M., and Almroth, E.: On the dynamics of oxygen, phosphorus and cyanobacteria in the Baltic Sea: A model study, J. Marine Syst., 75, 163-184, doi:10.1016/j.jmarsys.2008.08.009, 2009.

Ekau, W., Auel, H., Pörtner, H.-O., and Gilbert, D.: Impacts of hypoxia on the structure and processes in the pelagic community (zooplankton, macro-invertebrates and fish), Biogeosciences Discuss., 6, 5073-5144, 2009, http://www.biogeosciences-discuss.net/6/5073/2009/.

Eldridge, P. and Morse, J. W.: Origins and temporal scales of hypoxia on the Louisiana shelf: Importance of benthic and subpycnocline water metabolism, Mar. Chem., 108, 159-171, 2008.

Epping, E. A. G. and Helder, W.: Oxygen budgets calculated from in situ oxygen microprofiles for northern Adriatic sediments, Cont. Shelf Res., 17, 1737-1764, 1997. 
Fangohr, S. and Woolf, D. K.: Application of new parameterizations of gas transfer velocity and their impact on regional and global marine $\mathrm{CO}_{2}$ budgets, J. Marine Syst., 66, 195-203, 2007.

Fennel, K., Brady, D., Di Toro, D., Fulweiler, R. W., Gardner, W. S., Giblin, A., McCarthy, M. J., Rao, A., Seitzinger, S., ThouvenotKorppoo, M., and Tobias, C.: Modeling denitrification in aquatic sediments. Biogeochemistry, 93, 159-178, 2009.

Fennel, K., Wilkin, J., Levin, J., Moisan, J., O'Reilly, J., and Haidvogel, D.: Nitrogen cycling in the Middle Atlantic Bight: Results from a three-dimensional model and implications for the North Atlantic nitrogen budget, Global Biogeochem. Cy., 20, GB3007, doi:10.1029/2005GB002456, 2006.

Flynn, K. J.: Incorporating plankton respiration in models of aquatic ecosystem function, in: Respiration in aquatic ecosystems, edited by: del Giorgio, P. A. and Williams, P. J. le B., Oxford University Press Inc., New York, 248-266, 2005.

Fossing, H., Berg, P., Thamdrup, B., Rysgaard, S., Sorensen, H. M., and Nielsen, K.: A model set-up for an oxygen and nutrient flux model for Aarhus Bay (Denmark), National Environmental Research Institute (NERI), University of Aarhus, Technical Report, 483, 3601-3617, 2004.

Frölisher, T., Joos, F., Plattner, G.-K., Steinacher, M., and Doney, S. C.: Natural variability and anthropogenic trends in oceanic oxygen in a coupled carbon cycleclimate model ensemble, Global Biochem. Cy., 23, GB1003, doi:10.1029/2008GB003316, 2009.

Furukawa Y., Bentley, S. J., Shiller, A. M., Lavoie, D. L., and Van Cappellen, P.: The role of biologically-enhanced pore water transport in early diagenesis: An example from carbonate sediments in the vicinity of North Key Harbor, Dry Tortugas National Park, Florida, J. Mar. Res., 58, 493-522, 2000.

Garcia, H. E., Boyer, T. P., Levitus, S., Locarnini, R. A., and Antonov, J.: On the variability of dissolved oxygen and apparent oxygen utilization content for the upper world ocean: 1955 to 1998, Geophys. Res. Lett., 32, L09604, doi:10.1029/2004GL022286, 2005.

Garcia, H. and Gordon, L.: Oxygen solubility in seawater: Better fitting equations, Limnol. Oceanogr., 37, 1307-1312, 1992.

Gaspar, P., Gregoris, Y., and Lefevre, J.-M.: A simple eddy kinetic energy model for simulations of the oceanic vertical mixing: Tests at station Papa and long-term upper ocean study site, J. Geophys. Res., 95, 16179-16193, 1990.

Gassman, P. W., Reyes, M. R., Green, C. H., and Arnold, J. G.: The soil and water assessment tool: Historical development, applications, and future research directions, Transactions of the ASABE, 50, 1211-1250, 2007.

Gilbert, D., Sundby, B., Gobeil, C, Mucci, A., and Tremblay, G.-H.: A seventy-two year record of diminishing deep-water oxygen in the St. Lawrence Estuary: The northwest Atlantic connection, Limnol. Ocenogr., 50, 1654-1666, 2005

Gilbert, D., Rabalais, N. N., Diaz, R. J., and Zhang, J.: Evidence for greater oxygen decline rates in the coastal ocean than in the open ocean, Biogeosciences Discuss., 6, 9127-9160, 2009, http://www.biogeosciences-discuss.net/6/9127/2009/.

Glud, R. N.: Oxygen dynamics of marine sediments, Mar. Biol. Res., 4, 243-289, 2008.

Gnanadesikan, A., Russell, J. L., and Zeng, F.: How does ocean ventilation change under global warming?, Ocean Sci., 3, 43-53, 2007 , http://www.ocean-sci.net/3/43/2007/.

Green, R. E., Bianchi, T. S., Dagg, M. J., Walker, N. D., and Breed, G. A.: An organic carbon budget for the Mississippi River turbidity plume and plume contributions to air-sea $\mathrm{CO} 2$ fluxes and bottom water hypoxia, Estuaries Coasts, 29, 579-597, 2006.

Grégoire, M. and Friedrich, J.: Nitrogen budget of the northwestern Black Sea shelf as inferred from modeling studies and in-situ benthic measurements, Mar. Ecol.-Prog. Ser., 270, 15-39, 2004.

Grégoire, M. and Lacroix, G.: Study of the oxygen budget of the Black Sea waters using a 3-D coupled hydrodynamicalbiogeochemical model, J. Marine Syst., 31, 175-202, 2001.

Grégoire, M., Raick, C., and Soetaert, K.: Numerical modeling of the central Black Sea ecosystem functioning during the eutrophication phase, Prog. Oceanogr., 76, 286-333, 2008.

Hagy III, J. D. and Murrell, M. C.: Susceptibility of a northern Gulf of Mexico estuary to hypoxia: An analysis using box models, Estuar. Coast. Shelf Sci., 74, 239-253, 2007.

Heip, C. H. R., Goosen, N. K., Herman, P. M. J., Kromkamp, J., Middelburg, J. J., and Soetaert, K.: Production and consumption of biological particles in temperate tidal estuaries, Oceanogr. Mar. Biol., 33, 1-150, 1995.

Hetland, R. and DiMarco, S.: How does the character of oxygen demand control the structure of hypoxia on the Texas-Louisiana continental shelf?, J. Mar. Syst., 70, 49-62, doi:10.1016/j.jmarsys.2007.03.002, 2008.

Justić, D., Rabalais, N. N., and Turner, R. E.: Effects of climate change on hypoxia in coastal waters: A doubled $\mathrm{CO}_{2}$ scenario for the northern Gulf of Mexico, Limnol. Oceanogr., 41, 9921003, 1996.

Justić, D., Rabalais, N. N., and Turner, R. E.: Modeling the impacts of decadal changes in riverine nutrient fluxes on coastal eutrophication near the Mississippi River Delta, Ecol. Model., 152, 33-46, 2002.

Kantha, L. and Clayson, C.: Small scale processes in geophysical fluid flows, Academic Press, San Diego, California, 2000.

Karim, M. R., Sekine, M., and Ukita, M.: Simulation of eutrophication and associated occurrence of hypoxic and anoxic condition in a coastal bay in Japan, Mar. Pollut. Bull., 45, 280-285, 2002.

Karstensen, J., Stramma, L., and Visbeck, M.: Oxygen minimum zones in the eastern tropical Atlantic and Pacific oceans, Prog. Oceanogr., 77, 331-350, 2008.

Katsev, S., Chaillou, G., and Sundby, B.: Effects of progressive oxygen depletion on sediment diagenesis and fluxes: A model for the lower St. Lawrence River Estuary, Limnol. Oceanogr., 52, 2555-2568, 2007.

Katsev, S., Tsandev, I., L'Heureux, I., and Rancourt, D. G.: Factors controlling long term phosphorus efflux in lake sediments: Exploratory reaction-transport modeling, Chem. Geol., 234, 127147, 2006a.

Katsev, S., Sundby, B., and Mucci, A.: Modeling vertical excursions of the redox boundary in sediments: Application to deep basins of the Arctic Ocean, Limnol. Oceanogr., 51, 1581-1593, $2006 b$.

Keeling, R. F., Kortzinger, A., and Gruber, N.: Ocean deoxygenation in a warming world, Annu. Rev. Mar. Sci., 2, 463-493, 2010.

Kemp, W. M., Boynton, W. R., Adolf, J. E., Boesch, D. F., Boicourt, W. C., Brush, G., Cornwell, J. C., Fisher, T. R., Glibert, P. M., Hagy, J. D., Harding, L. W., Houde, E. D., Kimmel, D. G., 
Miller, W. D., Newell, R. I. E., Roman, M. R., Smith, E. M., and Stevenson, J. C.: Eutrophication of Chesapeake Bay: historical trends and ecological interactions, Mar. Ecol.-Prog. Ser., 303, 1-29, 2005.

Kemp, W. M., Testa, J. M., Conley, D. J., Gilbert, D., and Hagy, J. D.: Temporal responses of coastal hypoxia to nutrient loading and physical controls, Biogeosciences, 6, 2985-3008, 2009, http://www.biogeosciences.net/6/2985/2009/.

Kolesar, S. E: The effects of low dissolved oxygen on predation interactions between Mnemiopsis leidyi ctenophores and larval fish in Chesapeake Bay ecosystem, Ph. D. Thesis University of Maryland, Maryland, USA, 2006.

Konovalov, S. K., Murray, J. W., Luther, G. W., and Tebo, B. M.: Processes controlling the redox budget for oxic/anoxic water column of the Black Sea, Deep-Sea Res. II, 53, 1817-1841, 2006.

Kremp, C., Seifert, T., Mohrholz, V., and Fennel, W.: The oxygen dynamics during Baltic inflow events in 2001 to 2003 and the effect of different meteorological forcing - A model study, J. Mar. Syst., 67, 13-30, 2007.

Krom, M. D. and Berner, R. A.: The diagenesis of phosphorus in a nearshore sediment, Geochim. Cosmochim. Ac., 45, 207-216, 1981.

Kuypers, M. M. M., Sliekers, A. O., Lavik, G., Schmid, M., Jørgensen, B. B., Kuenen, J. G., Sinninghe Damsté, J. S., Strous, M., and Jetten, M. S. M.: Anaerobic ammonium oxidation by anammox bacteria in the Black Sea, Nature, 422, 608-611, 2003.

Larsson, U., Elmgren, R., and Wulff, F.: Eutrophication and the Baltic Sea: Causes and consequences, Ambio, 14, 9-14, 1985.

Levin, L. A., Ekau, W., Gooday, A. J., Jorissen, F., Middelburg, J. J., Naqvi, S. W. A., Neira, C., Rabalais, N. N., and Zhang, J.: Effects of natural and human-induced hypoxia on coastal benthos, Biogeosciences, 6, 2063-2098, 2009,

http://www.biogeosciences.net/6/2063/2009/.

Los, F. J., Villars, M. T., and Van der Tol, M. W. N.: A 3dimensional primary production model (BLOOM/GEM) and its application to the (southern) North Sea (coupled physicalchemical-ecological model), J. Mar. Syst., 74, 259-294, 2008.

Luff, R. and Moll, A.: Seasonal dynamics of the North Sea sediments using a three-dimensional coupled sediment-water model system, Cont. Shelf Res., 24, 1099-1127, 2004.

Matear, R. J., Hirst, A. C., and McNeil, B. I.: Changes in dissolved oxygen in the Southern Ocean with climate change, Geochem. Geophys. Geosys., 1, 1050, doi:10.1029/2000GC000086, 2000.

Matear, R. J. and Hirst, A. C.: Long-term changes in dissolved oxygen concentrations in the ocean caused by protracted global warming, Global Biogeochem. Cy., 17, 1125, doi:10.1029/2002GB001997, 2003.

McCarthy, M. J., McNeal, K. S., Morse, J. W., and Gardner, W. S.: Bottom- water hypoxia effects on sediment-water interface nitrogen transformations in a seasonally hypoxic, shallow bay (Corpus Christi Bay, Texas, USA), Estuaries Coasts, 31, 521531, 2008.

Meile, C. and Van Cappellen, P.: Global estimates of enhanced solute transport in marine sediments, Limnol. Oceanogr., 48, 777786, 2003

Mellor, G. L., and Yamada, T.: Development of a turbulence closure model for geophysical fluid problems, Rev. Geophys. Space Ge., 20, 851-875, 1982.
Meysman, F. J. R., Boudreau, B. P., and Middelburg, J. J.: Relations between local, nonlocal, discrete and continuous models of bioturbation, J. Mar. Res., 61, 391-410, 2003.

Meysman, F. J. R., Middelburg, J. J., and Heip, C. H. R.: Bioturbation: a fresh look at Darwin's last idea, Trends Ecol. Evol., 21, 688-695, 2006.

Middelburg, J. J. and Levin, L. A.: Coastal hypoxia and sediment biogeochemistry, Biogeosciences, 6, 1273-1293, 2009, http://www.biogeosciences.net/6/1273/2009/.

Middelburg, J. J, Soetaert, K., Herman, P., and Heip, C.: Denitrification in marine sediments: A model study, Global Biogeochem. Cy., 10, 661-673, 1996.

Morse, J. W. and Eldridge, P. M.: A non-steady state diagenetic model for changes in sediment biogeochemistry in response to seasonally hypoxic/anoxic conditions in the "dead zone" of the Louisiana shelf, Mar. Chem., 106, 239-255, 2007.

Naqvi, S. W. A., Jayakumar, D. A., Narvekar, P. V., Naik, H., Sarma, V. V. S. S., D’Souza, W., Joseph, S., and George, M. D.: Increased marine production of $\mathrm{N}_{2} \mathrm{O}$ due to intensifying anoxia on the Indian continental shelf, Nature, 408, 346-349, 2000.

Naqvi, S. W. A., Bange, H. W., Farías, L., Monteiro, P. M. S., Scranton, M. I., and Zhang, J.: Coastal hypoxia/anoxia as a source of CH4 and N2O, Biogeosciences Discuss., 6, 9455-9523, 2009, http://www.biogeosciences-discuss.net/6/9455/2009/.

Neumann, T.: Towards a 3D-ecosystem model of the Baltic Sea, J. Marine Syst., 25, 405-419, 2000.

Neumann, T., Fennel, W., and Kremp, C.: Experimental simulations with an ecosystem model of the Baltic Sea: A nutrient load reduction experiment, Global Biogeochem. Cy., 16, 1033, doi:10.1029/2001GB001450, 2002.

Nevison, C., Buttler, J. H., and Elkins, J. W.: Global distribution of $\mathrm{N}_{2} \mathrm{O}$ and the $\Delta \mathrm{N}_{2} \mathrm{O}$-AOU yield in the subsurface ocean, Global Biogeochem. Cy., 17, 1119, doi:10.1029/2003GB002068, 2003.

Oguz, T., Ducklow, H., and Malanotte-Rizzoli, P.: Modeling distinct vertical biogeochemical structure of the Black Sea: Dynamical coupling of the oxic, suboxic, and anoxic layers, Global Biogeochem. Cy., 14, 1331-1352, 2000.

Oguz, T., Ducklow, H., Purcell, J., and Malanotte-Rizzoli, P.: Modeling the response of top-down control exerted by gelatinous carnivores on the Black Sea pelagic food web, J. Geophys. Res.Oceans, 106, 4543-4564, 2001.

Olson, R.: Differential photoinhibition of marine nitrifying bacteria: a possible mechanism for the formation of the primary nitrite maximum, J. Mar. Res., 39, 227-238, 1981.

Oschlies, A., Schulz, K., Riebesell, U., and Schmittner, A.: Simulated 21 st century's increase in oceanic suboxia by $\mathrm{CO}_{2}$ enhanced biotic carbon export, Global Biogeochem. Cy., 22, GB4008, doi:10.1029/2007GB003147, 2008.

Pakhomova, S. V., Hall, P. O. J., Kononets, M. Y., Rozanov, A. G., Tengberg, A., and Vershinin, A. V.: Fluxes of iron and manganese across the sediment-water interface under various redox conditions, Mar. Chem., 107, 319-331, 2007.

Park, K., Kuo, A. Y., and Neilson, B. J.: A numerical model study of hypoxia in the tidal Rappahannock river of Chesapeake Bay, Estuar. Coast. Shelf Sci., 42, 563-581, 1996.

Paulmier, A., Kriest, I., and Oschlies, A.: Stoichiometries of remineralisation and denitrification in global biogeochemical ocean models, Biogeosciences, 6, 923-935, 2009, http://www.biogeosciences.net/6/923/2009/. 
Peña, M. A.: Modelling the response of the planktonic food web to iron fertilization and warming in the NE subarctic Pacific, Prog. Oceanogr., 57, 453-479, 2003.

Pearson, T. H. and Rosenberg, R.: Energy flow through the SE Kattegat: A comparative examination of the eutrophication of a coastal marine ecosystem, Netherlands J. Sea Res., 28, 317-334, 1992.

Reimers, C. E., Jahnke, R. A., and McCorkle, D. C.: Carbon fluxes and burial rates over the continental slope and rise off central California with implications for the global carbon cycle, Global Biogeochem. Cy., 6, 199-224, 1992.

Ritter, C. and Montagna, P. A.: Seasonal hypoxia and models of benthic response in a Texas bay, Estuaries, 22, 7-20, 1999.

Rowe, G. T.: Seasonal hypoxia in the bottom water off the Mississippi River Delta, J. Environ. Qual., 30, 281-290, 2001.

Sarmiento, J. L., Hughes, T. M. C., Stouffer, R. J., and Manabe, S.: Simulated response of the ocean carbon cycle to anthropogenic climate warming, Nature, 393, 245-249, 1998.

Savchuk, O. P. and Wulff, F.: Modeling the Baltic Sea eutrophication in a decision support system, Ambio, 36, 141-148, 2007.

Savchuk, O. P., Wulff, F., Hille, S., Humborg, C., and Pollehne, F.: The Baltic Sea a century ago - a reconstruction from model simulations, verified by observations, J. Mar. Syst., 74, 485-494, 2008.

Scavia, D. and Donnelly, K. A.: Reassessing hypoxia forecasts for the Gulf of Mexico, Environ. Sci. Technol., 41, 8111-8117, 2007.

Scavia, D., Kelly, E. L. A., and Hagy III, J. D.: A simple model for forecasting the effects of nitrogen loads on Chesapeake Bay hypoxia, Estuaries Coasts, 29, 674-684, 2006.

Scavia, D., Rabalais, N. N., Turner, R. E., Justić, D., and Wiseman, W. J. J.: Predicting the response of Gulf of Mexico hypoxia to variations in Mississippi River nitrogen load, Limnol. Oceanogr., 48, 951-956, 2003.

Schmittner, A., Oschlies, A., Matthews, H. D., and Galbraith, E. D.: Future changes in climate, ocean circulation, ecosystems, and biogeochemical cycling simulated for a buisness-as-usual $\mathrm{CO}_{2}$ emission scenario until year $4000 \mathrm{AD}$, Global Biogeochem. Cy., 22, GB1013, doi:10.1029/2007GB002953, 2008.

Shaffer, G., Olsen, S. M., and Pedersen, J. O. P.: Long-term ocean oxygen depletion in response to carbon dioxide emissions from fossil fuels, Nat. Geosci., 2, 105-109, 2009.

Shen, J., Wang, T., Herman, J., Masson, P., and Arnold, G. L.: Hypoxia in a coastal embayment of the Chesapeake Bay: A model diagnostic study of oxygen dynamics, Estuaries Coasts, 31, 652663,2008

Silverberg, N., Bakker, J., Edenborn, H. M., and Sundby, B.: Oxygen profiles and organic-carbon fluxes in Laurentian Trough sediments, Neth. J. Sea Res., 21, 95-105, 1987.

Slomp, C. P., Epping, E. H. G., Helder, W., and Van Raaphorst, W.: A key role for iron-bound phosphorus in authigenic apatite formation in North Atlantic continental platform sediments, J. Mar. Res., 54, 1179-1205, 1996.

Soetaert, K., Herman, P. M. J., and Middelburg, J. J.: A model of early diagenetic processes from the shelf to abyssal depths, Geochim. Cosmochim. Ac., 60, 1019-1040, 1996.

Soetaert, K., Middelburg, J. J., Herman, P. M. J., and Buis, K.: On the coupling of benthic and pelagic biogeochemical models, Earth-Sci. Rev., 51, 173-201, 2000.
Soetaert, K. and Middelburg, J. J.: Modeling eutrophication and oligotrophication of shallow-water marine systems: The importance of sediments under stratified and well-mixed conditions, Hydrobiologia, 629, 239-254, 2009.

Sohma, A., Sekiguchi, Y., Kuwae, T., and Nakamura, Y.: A benthicpelagic coupled ecosystem model to estimate the hypoxic estuary including tidal flat - Model description and validation of seasonal/daily dynamics, Ecol. Model., 215, 10-39, 2008.

Stramma, L., Johnson, G. C., Sprintall, J., and Mohrholz, V.: Expanding oxygen-minimum zones in the tropical oceans, Science, 320, 655-658, 2008.

Suntharalingam, P., Sarmiento, J. L., and Toggweiler, J. R.: Global significance of nitrous-oxide production and transport from oceanic low-oxygen zones: A modeling study, Global Biogeochem. Cy., 14, 1353-1370, 2000.

Tuchkovenko, Y. S. and Lonin, S. A.: Mathematical model of the oxygen regime of Cartagena Bay, Ecol. Model., 165, 91-106, 2003.

Turner, R. E., Rabalais, N. N., and Justić, D.: Predicting summer hypoxia in the northern Gulf of Mexico: Riverine N, P, and Si loading, Mar. Pollut. Bull., 52, 139-148, 2006.

Turner, R. E., Rabalais, N. N., and Justic, D.: Gulf of Mexico hypoxia: Alternate states and a legacy, Environ. Sci. Technol., 42, 2323-2327, 2008

Umlauf, L., Burchard, H., and Bolding, K.: General Ocean Turbulence Model, Scientific documentation. v3.2, Marine Science Reports 63, Baltic Sea Research Institute, Warnemünde, Germany, 274 pp., 2005.

Van Raaphorst, W., Ruardij, P., and Brinkman, A. G.: The assessment of benthic phosphorus regeneration in an estuarine ecosystem model, Neth. J. Sea Res., 22, 23-36, 1988.

Wallmann, K.: Feedbacks between oceanic redox states and marine productivity: A model perspective focused on benthic phosphorus cycling, Global Biogeochem. Cy., 17, 1084, doi:10.1029/2002GB001968, 2003.

Wang, L. and Justić, D.: A modeling study of the physical processes affecting the development of seasonal hypoxia over the inner Louisiana-Texas shelf: Circulation and stratification, Cont. Shelf Res., 29, 1464-1476, 2009.

Wanninkhof, R.: Relationship between wind speed and gas exchange over the ocean, J. Geophys. Res.-Oceans, 97, 7373-7382, 1992.

Wanninkhof, R., Asher, W. E., Ho, D. T., Sweeney, C., and McGillis, W. R.: Advances in quantifying air-gas exchange and environmental forcing, Annu. Rev. Mar. Sci., 1, 213-244, 2009.

Wilson, R. E., Swanson, R. L., and Crowley, H. A.: Perspectives on long-term variations in hypoxic conditions in western Long Island Sound, J. Geophys. Res.-Oceans, 113, C12011, doi:10.1029/2007JC004693, 2008.

$\mathrm{Xu}, \mathrm{J}$. and Hood, R. R.: Modeling biogeochemical cycles in Chesapeake Bay with a coupled physical-biological model, Estuar. Coast. Shelf Sci., 69, 19-46, 2006.

Yakushev, E. V. and Neretin, L. V.: One-dimensional modeling of nitrogen and sulfur cycles in the aphotic zones of the Black and Arabian Seas, Global Biogeochem. Cy., 11, 401-414, 1997.

Yakushev, E. V., Pollehne, F., Jost, G., Kuznetsov, I., Schneider, B., and Umlauf, L.: Analysis of the water column oxic/anoxic interface in the Black and Baltic seas with a numerical model, Mar. Chem., 107, 388-410, 2007. 
Yoshinari, T.: Nitrous oxide in the sea, Mar. Chem., 4, 189-202, 1976.

Zhang, J., Gilbert, D., Gooday, A., Levin, L., Naqvi, W., Middelburg, J., Scranton, M., Ekau, W., Pena, A., Dewitte, B., Oguz, T., Monteiro, P. M. S., Urban, E., Rabalais, N., Ittekkot, V., Kemp, W. M., Ulloa, O., Elmgren, R., Escobar-Briones, E., and
Van der Plas, A.: Natural and human-induced hypoxia and consequences for coastal areas: synthesis and future development, Biogeosciences Discuss., 6, 11035-11087, 2009, http://www.biogeosciences-discuss.net/6/11035/2009/. 